\title{
ON A COLLECTION OF DECAPOD AND STOMATOPOD CRUSTACEA FROM PULAU BERHALA, AN ISLET SITUATED IN THE STRAITS OF MALACCA
}

BY

\author{
DR. J. G. DE MAN, \\ of Ierseke.
}

(With 3 Plates.)

Mr. J. C. vAN DER MEER MOHR, Zoologist at the Deli-Station at Medan (Sumatra), has in 1926 and in August and December 1927 collected at Pulau Berhala 37 species and one variety of Decapod Crustacea and a variety of Gonodactylus chiragra (Fabr.); these species are described in this paper. As far as I am aware, the carcinological fauna of this islet was still entirely unknown.

The collection contains a new species of the genus Litocheira Kinahan, besides a new variety of Gonodactylus chiragra; among the others that are in the main common indo-pacific forms, two well-preserved males of the rare Grapsus gracilipes H. M.-Edw. and one fine specimen of Alpheus splendidus Cout., also a rare species, should especially be mentioned. Furthermore this paper, contains interesting remarks about a species of Pinnotheres from the shells of Arca granosa, collected at Indramajoe (Java), and, finally, detailed descriptions of Litoch. integra (Miers) and Litoch. subintegra Lanch., species which were still imperfectly known. Besides the species here described, also Menaethius monoceros (Latr.) and Panulirus versicolor (Latr.) are found at Pulau Berhala.

The figures have been drawn by the author.

LIST OF SPECIES.

Camposcia retusa Latr.

Carpilodes tristis Dana

Carpilodes margaritatus A. M.-Edw.

Xanthias punctatus (H. M.-Edw.)

Atergatis integerrimus (Lam.)

Atergatis floridus (Rumphius)

Euxanthus melissa (Herbst)

Leptodius exarätus (H. M.-Edw.)

Leptodius cavipes (Dana)

Chlorodiella nigra (Forskål)

Chlorodopsis melanochira A. M.-Edw.

Pilumnus Sluiteri de Man

Pilumnus levimanus Dana
? Pilumnus hirsutus Stimpson

Actumnus changensis Rathb.

Eriphia laevimana Latr.

Eriphia laevimana Latr. var. Smithii Macleay

Charybdis (Goniosoma) erythrodactyla (Lam.)

Thalamita Danae Stimpson

Thalamita prymna (Herbst)

Thalamita admete (Herbst)

Litocheira șetosa (A. M.-Edw.)

Litocheira subintegra Lanch.

Litocheira splendida n. sp.

Litocheira integra (Miers)

Pinnotheres palaensis Bürger. 
Ocypoda ceratophthalma (Pallas) Grapsus gracilipes H. M.-Edw. Grapsus strigosus (Herbst)

Varuna litterata (Fabr.)

Sesarma (Sesarma) ocypoda Nobili Metasesarma Rousseauxi H. M.-Edw. Gecarcoidea Lalandii H. M.-Edw. Cryptodromia canaliculata Stimpson
Petrolisthes dentatus (H. M.-Edw.) var. Petrolisthes Boscii (Aud.)

Clibanarius virescens Krauss

Coenobita clypeatus Latr.

Coenobita cavipes Stimpson

Alpheus splendidus Cout.

Alpheus chiragricus H. M.-Edw.

Gonodactylus chiragra Fabr. var. intermedia n.

Camposcia retusa Latr.

Camposcia retusa Latr., A. Alcock, Materials for a Carcinological Fauna of India. $\mathrm{N}^{0}$ 1. The Brachyura Oxyrhyncha. Calcutta 1895, p. 184, in: Journal Asiatic Soc. of Bengal, Vol. LXIV, Part II, No 2, 1895.

One adult female, carapace and legs densely encrusted with sponges, zoophytes, algae etc. Carapace $35 \mathrm{~mm}$. long.

\section{Carpilodes tristis Dana.}

Carpilodes tristis Dana, A. Alcock, Materials for a Carcinological Fauna of -India. № 3 . The Brachyura Cyclometopa. Part I. The Family Xanthidae. Calcutta 1898, p. 82, in: Journal Asiatic Soc. of Bengal. Vol. LXVII, Part II, N0 1, 1898. - J. G. DE MAN, in: Notes from the Leyden Museum, Vol. XII, 1890, p. 50.

One female without eggs.

The carapace is $28,5 \mathrm{~mm}$. broad and $16 \mathrm{~mm}$. long, distance between the external orbital angles, that are not at all prominent, $13 \mathrm{~mm}$. The upper surface of the carapace is of a dull grayish colour, with a reddish tinge on the cardiac region and less so on the gastric, anterior border of the front and lower side of the orbits and of the antero-lateral borders red, abdomen reddish laterally; outer and upper side of the chelipeds red, fingers black, dactylus red at base, ambulatory legs red with the articulations white.

The legs of the $5^{\text {th }}$ pair are $19 \mathrm{~mm}$. long, merus $6,5 \mathrm{~mm}$. long, $3,1 \mathrm{~mm}$. broad. This specimen is certainly full-grown, larger than that of Dạna.

Carpilodes margaritatus A. M.--Edw.

Carpilodes margaritatus A. Milne Edwards, in: Nouv. Archives du Muséum, T. IX, 1873, p. 182, PI. V, Fig. 2 Carpilodes margaritatus T. Odhner, Monographierte Gattungen der Krabbenfamilie Xanthidae, Göteborg 1925, p. 24, Taf. 2, fig. 4, in: Göteborgs Kungl. Vetenskaps - och Vitterhets - samhälles Handlingar. Band 29. N:o 1. (ubi synonyma).

One male and one female without eggs.

The carapace of the female is $16 \mathrm{~mm}$. broad, that of the male $13 \mathrm{~mm}$. Carapace and legs are above uniformly purple-coloured, without any trace of striae. As was already observed by Targioni Tozzetti in 1877 (Chlorodius exiguus) and by Henderson in 1893 the pearly granulations show on the chelae a tendency to linear arrangement. The regio post-mediana $4 \mathrm{M}$. of Dana is distinctly defined by a groove, which is less deep than the others. On the middle of the anterior cardiac region the granules flow partly together, so that the surface appears here rather rugose or eroded.

According to HENDERSON the carapace attains a width of $27,5 \mathrm{~mm}$.

Carpilodes Hartmeyeri Odhner from Sharks bay, West-Australia, should perhaps be considered as a variety of this species.

\section{Xanthias punctatus (H. M.-Edw.).}

Lioxantho punctatus (H. Milne-Edwards), A. Alcock, 1. c. 1898, p. 91. Confer: T. ODHNER; 1. c. p. 84.

One adult male.

The small, circular, red spots that characterize this species, are distinctly visible on the upper surface of the carapace and on the pterygostomian regions. The chelipeds are equal. The carapace is $30 \mathrm{~mm}$. broad, $19 \mathrm{~mm}$. long and the distance between the external orbital angles measures $14 \mathrm{~mm}$. 
It appears to me doubtful whether in 1890 a male and a female from unknown locality have rightly been referred by me to this species (J. G. DE MAN, in: Notes from the Leyden Museum, Vol. XII, p. 52, Pl. 3, fig. 1). Not only was the right cheliped of the male considerably larger than the left, - in the female the chelipeds were equal, but this is often the case in the female also of other species -, but the distance between the external orbital angles was, both in the male and in the female, much smaller, when compared with the greatest breadth of the carapace, than in the male from Pulau Berhala. The specimens, described in 1890, should perhaps be referred to Xanthias tumidus (Alcock).

\section{Atergatis integerrimus (Lam.).}

Atergatis integerrimus Lamarck, A. Alcock, 1.c. 1898, p. 95.

Confer: J. G. DE MAN, in: Zoolog. Mededeelingen uitgegeven vanwege 's Rijks Museum van Natuurlijke Historie, Leiden, Deel IX, 1926, p. 205.

Five young males. In the largest specimen the carapace is $42 \mathrm{~mm}$. broad and $25 \mathrm{~mm}$. long, in the youngest $26 \mathrm{~mm}$. broad and $16 \mathrm{~mm}$. long. The full-grown male and the female that had nearly the same size, from Batavia, with which I have dealt in 1926, 1. c., are lying before me; of the male the carapace is $94 \mathrm{~mm}$. broad and $60 \mathrm{~mm}$. long. In the largest male from Pulau Berhala the rounded distant pits on the anterior third or half of the upper surface of the carapace are already as numerous and comparatively as large as in the full-grown male from Batavia and are 0,5-0,8 mm. broad. In a male of which the carapace is $38 \mathrm{~mm}$. broad, the external maxillipeds are closely covered with long thick yellowish bristles, in other specimens the merus and the exopod are already devoid of hair. Col. ALCOcK made use of this character for distinguishing A. dilatatus from $A$. integerrimus, in my opinion wrongly, but these two species are easily distinguished by the antero-lateral margins that in $A$. dilatatus end posteriorly in a conical tooth, which in A. integerrimus is wanting (DE HAAN, Fauna Japonica, Crustacea, Tab. XIV, fig. 2).

Measured along the upper border the merus of the legs of the $5^{\text {th }}$ pair proves to be $19 \mathrm{~mm}$. long and $10,2 \mathrm{~mm}$. broad in the full-grown male of $A$. integerrimus from Batavia; in the largest male from Pulau Berhala these numbers are $9 \mathrm{~mm}$. and $5,1 \mathrm{~mm}$.

\section{Atergatis floridus (Rumphius).}

Atergatis floridus (Rumphius), A. Alcock, 1. c. 1898, p. 98.

Fifteen specimens of various size, seven males and eight females, four of which are egg-bearing. The largest is a male, the carapace of which is $49 \mathrm{~mm}$. broad and $34 \mathrm{~mm}$. long; the carapace of the largest ova-bearing female is $37 \mathrm{~mm}$. broad, that of the smallest female with eggs $29 \mathrm{~mm}$. and the carapace is in these two females $25 \mathrm{~mm}$., respectively $19,5 \mathrm{~mm}$. long. The breadth and length of the carapace of the two youngest males are in one $14 \mathrm{~mm}$. and $9 \mathrm{~mm}$., in the other $12,5 \mathrm{~mm}$. and $8,75 \mathrm{~mm}$.

The pattern of the symmetrically disposed brown spots and confluent blotches on the upper surface of the carapace is very variable, no one specimen fully resembles another. In the young male of which the carapace is $14 \mathrm{~mm}$. broad, the upper surface of the carapace has a whitish colour, on which one observes on the middle a few yellow spots and on the front and on the margins red blotches, but the legs are coloured as in the larger specimens; in the youngest male the whole animal is above dark red, without spots or blotches.

\section{Euxanthus melissa (Herbst).}

Euxanthus melissa (Herbst), A. Alcock, 1.c. 1898, p. 110.

Two males and three females, one of which is egg-bearing.

The largest specimen is a male; of which the carapace at the $4^{\text {th }}$ antero-lateral teeth presents the greatest width of $41 \mathrm{~mm}$; the carapace of the largest female is $40 \mathrm{~mm}$., that of the ova-bearing female $37,5 \mathrm{~mm}$. broad. 
Leptodius exaratus (H. M.-Edw.).

Xantho (Leptodius) exaratus H. Milne Edwards, A. Alcock, 1. c. 1898, p. 118.

Five males and three females, all young.

The largest specimen is a male, of which the carapace is $18 \mathrm{~mm}$. broad, $12 \mathrm{~mm}$. long.

Leptodius cavipes (Dana).

Chlorodius cavipes J. D. Dana, U. S. Explor. Exped. Crust. Pt. I, p. 212, Pl. 12, fig. $1 a$ and $b$.

Xantho (Leptodius) cavipes A. Alcock, 1.c. 1898, p. 122.

Leptodius cavipes M. J. Rathbun, in: The Transactions of the Linnean Soc. of London, $2^{\text {nd }}$ Ser. Zoology,

Vol. XIV. Part 2, London 1911, p. 216, Pl. 18, fig. 10.

Two full-grown males and two egg-bearing females.

Dana's figure of the whole animal is not quite accurate, the areolae $2 \mathrm{M}$. appear in this figure undivided, whereas they show anteriorly a trace of a longitudinal furrow, dividing the areola anteriorly in a larger outer and a smaller inner part. All the lobes of the anterior two-thirds of the upper surface have an imbricate look, which in Dana's figure is indistinct, and the left cheliped appears tuberculate instead of wrinkled. Fortunately Miss RathBun has published (1. c.) a much better figure.

The carapace of the largest specimen, a male, is $20,5 \mathrm{~mm}$. broad and $13 \mathrm{~mm}$. long, that of the larger ova-bearing female is $19,5 \mathrm{~mm}$. broad, $12,5 \mathrm{~mm}$. long, in the other female these numbers are $15,5 \mathrm{~mm}$. and $10 \mathrm{~mm}$.

This species is at present known from the Bonin Islands, Owen Island (Mergui Archipelago), the Andamans, Ceylon, Indian Ocean (Peros, Coin).

\section{Chlorodiella nigra (Forskål).}

Chlorodius niger (Forskăl), J. G. de Man, in: The Journal of the Linnean Society of London, Zoology, Vol. XXII, 1888, p. 32.

One young male, the carapace of which is $10 \mathrm{~mm}$. broad.

Like in the specimens from Elphinstone Island, the two posterior antero-lateral teeth are acute, spiniform and obliquely directed forward. The carapace and chelipeds are of a dark purplish colour, also the ambulatory legs, but the distal end of the merus, the carpus and the base of the dactyli are red, the distal half of the dactyli yellow; these legs are very hairy, especially the carpus and propodus.

Chlorodopsis melanochira A. M.-Edw.

Chlorodopsis melanochira A. M.-Edw., A. Alcock, 1.c. 1898, p. 168.

Fourteen specimens, nine males and five females.

In all the male specimens the chelipeds are markedly unequal and show the characteristic black colouration of the immobile finger extending far back along the palm. The largest specimen is a male, of which the carapace is $15 \mathrm{~mm}$. broad; two ova-bearing females that apparently belong to this species, are of a very small size, the carapace being in one $8 \mathrm{~mm}$., in the other even only 7,5 mm. broad; in the former the left cheliped appears a little larger than the right, in the other the right is lost.

According to Dr. Alcock (1. c.) the chelipeds of Chlor. pilumnoides (Ad. and White) should be subequal, but in the figure 3 of this species on Plate IX of the Voyage of H.M.S. Samarang, that represents a full-grown male, the left cheliped appears considerably larger than the right.

The carapace of this species attains a breadth of $18 \mathrm{~mm}$. (A. MiLne EDWARDs).

Pilumnus Sluiteri de Man.

Pilumnus sluiteri de Man, A. Alcock, 1.c. 1898, p. 194 (ubi literatura).

Two well-preserved males.

The carapace of the larger specimen is $32 \mathrm{~mm}$. broad, $26 \mathrm{~mm}$. long (the median frontal lobes 
included), and the external orbital angles are $19 \mathrm{~mm}$. distant from one another; in the other male these numbers are in the same succession $25 \mathrm{~mm} ., 21 \mathrm{~mm}$. and $16 \mathrm{~mm}$.

Pil. Forskalii H. M.-Edw., that inhabits the Red Sea, of which Paulson and Nobill have published detailed descriptions and good figures, may easily be distinguished by the following. The upper surface of the carapace bears numerous tubercles and granules, well-visible on PAULSON's figure 1 of Pl. VII of his work of 1875, whereas Pil. Sluiteri bears only some sharp granules near and between the antero-lateral. spines, a few small granules also sometimes on the anterior part of the gastric region and on the postero-lateral borders: The outer frontal teeth are in Pil. Forskalii spiniform, in Pil. Sluiteri triangular, obtuse; the external orbital angle, spiniform in Pil. Forskalii, is represented in Pil. Sluiteri by a subacute granule, which is barely larger than the other granules of the orbital margin. The triangular, inner, suborbital lobe, acute in Pil. Forskalii, is obtuse in Pil. Sluiteri, in Pil. Forskalii one observes a well-developed subhepatic spine, which in Pil. Sluiteri is wanting. The granulation on the upper surface of the carpus of the anterior legs is more developed in Pil. Forskalii.

In the larger male of Pil. Sluiteri the outer surface of the palm of the larger chela, that is placed on the right side, appears smooth, finely punctate just near the lower border, but the lower border itself bears a few obtuse granules of unequal size, that are not continued on that of the fixed finger; of the smaller chela the whole outer surface is covered with granules. In the other smaller male the granules of the outer surface of the larger cheliped, here placed on the left side, extend also to the lower border, but are near this border rather obtuse.

The upper surface of carapace and legs is of a purple colour, on either side of the cardiac region one observes a pale yellowish spot and the outer surface of the chelae is also of a paler colour; fingers black.

\section{Pilumnus levimanus (Dana) A. M.-Edw.}

Pilumnus levimanus J. D. Dana, U. S. Explor. Exped. Crust. I, p. 237, P1. 13, fig. 11a, b.

Pilumnus levimanus A. Milne Edwards, in: Nouv. Archives du Muséum, Mémoires, T. IX, Paris 1873, p. 250, P1. X, fig. 4.

Pilumnus laevimanus J. G. de Man, in: Archiv f. Naturgeschichte, 53. Jahrg., Berlin 1888, p. 301.

One male and three females, one of which is provided with eggs.

The largest specimen is the ova-bearing female, the carapace of which is $8,75 \mathrm{~mm}$. broad and $6 \mathrm{~mm}$. long, distance between the supero-internal angles of the orbits $3 \mathrm{~mm}$. The somewhat convex frontal lobes are directed obliquely backward and separated from the obtuse supero-internal angles of the orbits by a shallow notch; upper border of the orbits devoid of gaps or notches, outer angle unarmed, not at all prominent. The three antero-lateral teeth are acute, spiniform and curved forward, distance between the apices of the 1 st and 3 rd one and a half times as long as the distance between the apex of the 1 st and the outer orbital angle; epigastric lobes smooth, rather prominent; between these lobes and the frontal border, a little nearer to the latter than to the former, on either side a transverse granulated line, beset with rather long yellow hairs. Similar hairs are also implanted near the antero-lateral borders.

Antennal flagella a little longer than the width of the front, glabrous. In the four specimens the larger cheliped is placed at the right side, in that of A. MilnE-EDWARDS on the left.

The upper surface of the carapace, of the carpal joints of the chelipeds and of the ambulatory legs is of a pale reddish colour; from the median incision of the front a narrow milk-white band runs backward to just behind the epigastric lobes, parallel with it a similar milk-white band runs backward from the notch between the front and the upper orbital border and these two are united, just behind the epigastric lobes, by a transverse band of the same colour, a somewhat broader milkwhite band runs from the external orbital angle to the 1st antero-lateral tooth, a milk-white spot occurs just before the 2nd and the 3rd teeth, the shallow cervical groove, finally, that defines the gastric region posteriorly, is marked by a milk-white $\mathrm{W}$-shaped figure.

The outer surface of the larger chela appears near the wrist still somewhat reddish, but this colour changes gradually into a white colour to the base of the fingers, that for the rest are black, 
not grooved; the outer side of the smaller chela is of a pale red, covered with a short tomentum with a few longer hairs; the grooved fingers of this chela are black, but white at their base. The upper surface of the carpus of the larger cheliped is smooth in the middle, and covered like the three last joints of the ambulatory legs with long yellow hairs; these hairs are drawn too short in the figure of A. MiLNE-EDWARDs's paper. The mero-carpal articulations of the ambulatory legs are milk-white and a transverse band of the same colour is observed just beyond the middle of the merus.

Eggs very numerous, orange-coloured, globular, $0,4 \mathrm{~mm}$. broad.

It appears to me not quite certain whether A. MILNE-EDwARDS was right when referring his specimens to DANA's species. In DANA's species, indeed, the distance between the upper borders of the orbits is broader, according to his figure, than in the specimens described above: in Dana's figure the carapace is $24,5 \mathrm{~mm}$. broad; the distance between the upper orbital borders $11,5 \mathrm{~mm}$., in the ova-bearing female from Pulau Berhala these numbers are $8,5 \mathrm{~mm}$. and $3,5 \mathrm{~mm}$. The rather prominent, epigastric lobes are in DANA's figure not visible, the antero-lateral teeth are described as being not acute, the upper surface of the carpus of the larger cheliped, finally, as "obsolete tuberculate", while it is indeed quite smooth, at least in the middle.

Pilumnus levimanus (Dana) A. M.-Edw. is distributed from New Caledonia, through the Indian Archipelago (Bay of Batavia), to the Straits of Malacca.

\section{? Pilumnus hirsutus Stimpson.}

Pilumnus hirsutus W. Stimpson, in: Smithsonian Miscellaneous Collections; Part of Vol. XLIX, Wash. 1907, p. 69, P1. IX, fig. 1.

One young male.

The antero-lateral margins of the carapace which is $7 \mathrm{~mm}$. broad and $5 \mathrm{~mm}$. long, are armed with four slender spines, including the spine at the outer angle of the orbit. Larger cheliped on the right side, the whole outer surface of the palm is still tuberculate.

Actumnus changensis Rathb. (P1. I, Fig. 1).

Actumnus changensis M. J. Rathbun, in: D. Kgl. Danske Vidensk. Selsk. Skrifter, 7. Raekke, Naturvidensk. og Mathem. Afd. V. 4, København, 1910, p. 357, fig. 41.

One male and one ova-bearing female.

The carapace of the male is $6,3 \mathrm{~mm}$. broad, $4,4 \mathrm{~mm}$. long, that of the female $5,7 \mathrm{~mm}$. broad, $3,8 \mathrm{~mm}$. long.

The coloration of the two specimens is quite different, but I cannot say whether this is owing to a different working of the spirits or whether it is a sexual character. The prime colour of the carapace of the male is a pale straw-colour, the hepatic region and the antero-lateral teeth, excepting the last one, are orange, like the frontal border and the median line of the carapace nearly to the middle; the cardiac region is adorned with four circular orange spots, two in the midline anteriorly and on each side near the posterior border. On the lower surface the subhepatic region and the external maxillipeds are also of a pale orange. The upper surface of the merus, carpus and palm of the chelipeds is also orange, darkest on the carpus, on the outer side of the palm the orange passes gradually into the straw colour, that show also the fingers, excepting the orange base of the dactylus; the ambulatory legs are, like the inner surface of the chelipeds, straw-coloured, the upper border of the merus, carpus and propodus of these legs is partly orange.

In the female the upper surface of the carapace and of the legs is green-coloured, darker near the antero-lateral teeth, the free border of these teeth, the upper orbital border and that of the front are of a pale colour; on the chelipeds and the other legs the orange of the male is here substituted by a sooty colour.

One reads in the original description: "there are three antero-lateral teeth, the first subtruncate, the second and third acutely pointed. Between the first tooth and the orbital angle there is a spinule". Both in the male and the female from Pulau Berhala one does not observe a "spinule", but a 
barely prominent lobe, that is much less prominent than the following subtruncate tooth and that measures two-thirds the length of the latter. This species bears therefore not three, but four anterolateral teeth; the first tooth is a truncate lobe, the second is subtruncate, the third and the fourth are acutely pointed; the free border of the four teeth appears, under the microscope, denticulate, the denticles acute and sharp, 6 on the first lobe, 11 or 12 on the second, 4 or 5 on the third, 7 or 8 on the last.

The upper orbital margin and the frontal border are finely granulate, the former without gaps or notches; not only the antero-lateral parts of the carapace but also the front and the anterior half of the gastric region are covered with separate granules, between which short hairs are implanted.

Eggs numerous, globular, diameter $0,32 \mathrm{~mm}$.

This dwarfish species was hitherto only known from Koh Chang, eastern coast of the Gulf of Siam.

\section{Eriphia laevimana Latr.}

Eriphia laevimana Latr., A. ALcock, 1.c. 1898, p. 214.

Four adult females of somewhat unequal size, two of which are ova-bearing.

The carapace of the largest specimen is $55 \mathrm{~mm}$. broad, of the larger ova-bearing female $50 \mathrm{~mm}$., of the other ova-bearing specimen $46 \mathrm{~mm}$., of the last specimen $44 \mathrm{~mm}$. In the largest specimen and in the two ova-bearing females the right cheliped is the larger, in the last specimen it is the left.

Eriphia laevimana Latr., var. Smithii Macleay.

Eriphia Laevimana var. Smithii Macleay, A. ALcock, 1. c. 1898, p. 216.

Two full-grown females, one of which is ova-bearing.

The carapace of the ova-bearing female is $62 \mathrm{~mm}$. broad, that of the other $57 \mathrm{~mm}$.

\section{Charybdis (Goniosoma) erythrodactyla (Lam.).}

Charybdis (Goniosoma) erythrodactyla (Lam.), H. C. DELSMAN and J. G. DE MAN, On the "Radjungans” of the Bay of Batavia. Batavia 1925, p. 311 and 316, Pl. XVa, in: Treubia, Vol. VI, Livr. 3-4, Décembre 1925 (ubi literatura).

One beautiful ova-bearing female, of which the carapace is $70 \mathrm{~mm}$. broad.

According to A. MiLnE-Edwards in his Monograph of the Portunidae of 1861 the carapace of this species attains a breadth of 12 centimeters. In this specimen from Pulau Berhala all the teeth of the carapace are acuminate with black apices; in the specimen, figured on Plate XV of our paper on the "Radjungans"; the lateral margins of the frontal teeth are slightly curved, but in the female from Pulau Berhala these margins are quite straight, so that the frontal teeth appear triangular and acuminate. They agree with the description of 1834 in the "Histoire Nat. des Crustacés", where the frontal teeth are described as "longues et aiguës"; in the quoted Monograph of the Portunidae, however, one reads "front à huit dents larges, épaisses, obtuses" and the specimen from which this description was taken and which was collected at Nuka-Hiva, has in 1906 been figured by Dr. Nobill, in: Bull. Scientif. France et Belgique, XL, 1906, p. 118, fig. 3. We must evidently conclude that in this specimen from. Nuka-Hiva the frontal teeth were worn off.

The white coloured, compressed tubercle on the basal joint of the outer antennae is welldeveloped and terminates in two black spines, of which the inner is a little larger than the outer. The tubercle on the lower side of the front at the incision between the 1 st and 2nd frontal teeth, counting from the midline, is also quite distinct.

Right cheliped little larger than the left. Anterior border of the arms with 4 spines of which the two middle ones are twice as large as the two others; chelae with 5 spines; the tubercle at the proximal extremity of the upper inner border, that A. MILNE-EDWARDS describes as spiniform, appears in both chelae rounded, obtuse.

The large, round, red fleck on the branchial regions is well-visible. 
Thalamita Danae Stimpson.

Thalamita Danae Stimpson, A. ALCock, Materials for a Carcinological Fauna of India. N0 4 . The Brachyura Cyclometopa. Part II. The families Portunidae, Cancridae and Corystidae. Calcutta 1899, p. 77 (in: Journal Asiatic Soc. of Bengal, Vol. LXVIII, Part II, $\mathrm{N}^{0} 1$ ).

One egg-bearing female. Carapace $39 \mathrm{~mm}$. broad.

Thalamita prymna (Herbst).

Thalamita prymna (Herbst), A. ALCOCK, 1. c. 1899, p. 78.

Five specimens, viz., an adult male, an ova-bearing female and three young specimens.

The carapace of the adult male is $46,5 \mathrm{~mm}$. broad, that of the ova-bearing female $42,5 \mathrm{~mm}$.

Thalamita admete (Herbst).

Thalamita admete (Herbst), A. Alcock, 1. c. 1899, p. 82.

One ova-bearing female, of which the carapace is almost $16 \mathrm{~mm}$. broad.

Litocheira setosa (A. M.-EDw.).

Carcinoplax setosus A. Milne Edwards, in: Nouv. Archives du Muséum. Mémoires, T. IX, Paris 1873, p. 267, P1. XII, fig. 2.

Carcinoplax setosus J. G. đe Man, in: Archiv f. Naturg. 53. Jahrg. Berlin 1888, p. 349.

Litochira setosa A. Alcock, Materials for a Carcinological Fauna of India. N0 6 . The Brachyura Catometopa or Grapsoidea. Calcutta 1900, p. 315 (Journal Asiatic Soc. of Bengal, Vol. LXIX, Part II, No 3, 1900).

Litocheira setosa J. J. Tesch, The Decapoda Brachyura of the Siboga Expedition. Il. Goneplacidae and

Pinnotheridae. Leiden 1918, p. 165, Pl. I, fig: 1. (Monographe XXXIX $c^{1}$ ).

? Litocheira integra R. Douglas Laurie, in: The Journal of the Linnean Society. Zoology. Vol. XXXI. London 1915, p. 464, PI. 45, fig. 2.

One male and two females, one of which is provided with eggs, from Pulau Berhala.

The male from Noordwachter Island, described by me in 1888 (1. c.), belongs to my private collection and is lying before me; the carapace of this specimen is 9,25 mm. broad and $6,3 \mathrm{~mm}$. long, transversely flattened, only a little declivous towards the lateral borders. The male from Pulau Berhala is $11 \mathrm{~mm}$. broad, while the carapace is $7,4 \mathrm{~mm}$. long, once and a half as broad as long; in this specimen the branchial regions are $\mathrm{much}$ inflated and convex dorsally so as to make the transverse plane of the carapace strongly concave in the middle above the mesogastric region; the postero-lateral borders converge also more backward than in the male from Noordwachter Island. The carapace of this male has therefore a different outer appearance, which, I suppose, is due to this specimen being full-grown; it is indeed larger than all the specimens heretofore observed. The inflated branchial regions are of a pale red colour, the gastric region is blood-coloured, with. a narrow white stripe running in the middle line, slightly widening, backward to the mesogastric region; the postero-lateral and the intestinal regions are whitish, the former with one or two oblique, blood-coloured bands. The ambulatory legs are red; the larger chela is wanting, in the left, apparently the smaller, the upper surface of the carpus and the inner of the chela are also red, the rest of a paler colour, distal half of the pointed fingers black. The pterygostomian and subhepatic regions and the epistome are reddish, the basal joint of the outer antennae and the anterior border of the buccal cavern whitish, external maxillipeds, sternum and abdomen straw-coloured. The anterolateral borders bear two subacute teeth, no spines.

The carapace of the ova-bearing female is $8,5 \mathrm{~mm}$. broad, $6 \mathrm{~mm}$. long, that of the other female $6,5 \mathrm{~mm}$. broad, $5 \mathrm{~mm}$. long. In both females the anterior half of the upper surface of the carapace is pale reddish, in the smaller female the postero-lateral borders and the cardiac region also, the rest whitish; in both females the two teeth on the antero-lateral,border are spiniform.

Eggs very numerous, globular, diameter $0,56-0,6 \mathrm{~mm}$.

I am indebted to the courtesy of Professor JAMES JoHnstone of the University of Liverpool 
for having been able to examine three specimens from the Sudanese Red Sea, which were referred by R. Douglas Laurie to Litoch. integra (Miers), viz., the numbers 385 (very young female), 386 (ova-bearing female) and 384 (male), the only numbers that are still extant in the Liverpool Museum. The examination proved that these specimens certainly not belong to Litoch. integra (Miers 1884), but that they perhaps should be referred to Litoch. setosa (A. M.-Edw.). In the youngest specimen $\mathrm{N}^{0} 385$, the carapace of which is only $3,5 \mathrm{~mm}$. broad, the antero-lateral margins are armed with two spiniform teeth, as in Litoch. setosa, in the male $\mathrm{N}^{0} .384$ one observes on these margins distinctly the two prominences characteristic of Litoch. setosa, though being here not spiniform, in the ovabearing female $\mathrm{N}^{0} 386$, finally, the two prominences are indistinct, but for the rest it agrees with the two others. In all the specimens the whole upper surface of the carapace is covered with a close short pubescence, that in adult specimens of Litoch. setosa is wanting on the greater part of the upper surface. In all the specimens the carapace appears less broad in proportion to its length than in Litoch. integra. The globular eggs of the female $\mathrm{N}^{0} 386$ show a diameter of $0,5 \mathrm{~mm}$.

The nearest related species of Litoch. setosa is, no doubt; Litoch. vestita (de Haan) from Japan, a species that probably has been collected by the "Challenger" in Japan, though in the Report on the Challenger Brachyura the collected specimens were referred (p. 229). by Miers to a variety sexdentata (Haswell) and to the genus Pilumnoplax Stimpson. Unfortunately Mr. Miers did not compare the specimens with Litoch. setosa. This must be left to later researches.

Litocheira setosa (A. M.-Edw.) is at present known from New Caledonia (A. Milne Edwards), Banda (DE MAn, TeSCH), Ambon (Tesch), Taruna Bay, Great Sangir Island, between Celebes and the Philippines (TESCH), Nangamessi Bay, north coast of Sumba (TESCH), Labuan Pandan, east coast of Lombok (TESCH), Noordwachter Island, Bay of Batavia (DE MAN), East of Koh Chuen, Siam (RATHBUN), Mergui (AlcocK), Andamans (Alcock).

\section{Litocheira subintegra Lanch. (Pl. I, Fig. 2-2d).}

Carcinoplax subinteger W. F. Lanchester, in: Proc. Zool. Soc. London, 1900, p. 750, P1. XLVI, fig. $9 a$. Carcinoplax integer J. G. de Man, in: The Journal Linnean Soc. London, 1888, Vol. XXII, p. 93. Litochira integra A. Alcock, 1. c. 1900, p. 314.

? Carcinoplax subinteger hirsutior W. F. Lanchester, 1. c. p. 751.

Nec.: Litocheira subintegra J. J. Tesch, The Decapoda Brachyura of the Siboga Expedition. II. Goneplacidae and Pinnotheridae. Leiden 1918, p. 175, Pl. 16, fig. 1 (Monographe.XXXIX $c^{1}$ ).

In 1888 three specimens, two males and a female, from Elphinstone Island in the Mergui Archipelago were wrongly referred by me (l. c.) to Carcinoplax integer Miers $=$ Litocheira integra (Miers). Of these three specimens the two males are preserved in the British Museum, London, the female in the Indian Museum, Calcutta (Lanchester (1. c.), Alcock (1. c.)). Upon my request Dr. Calman kindly enabled me to examine the larger of the two males from Elphinstone Island, after which the figures $2-2 d$ have been drawn; unfortunately this specimen misses both chelipeds.

The carapace of this male is $10,25 \mathrm{~mm}$. broad and $7,75 \mathrm{~mm}$. long, without the abdomen of course; the unarmed external orbital angles are $6,3 \mathrm{~mm}$. distant from one another, the front is $3,5 \mathrm{~mm}$. broad. The ratio between length and breadth being 1,32 , the carapace appears $\mathrm{much} l \mathrm{l} s \mathrm{~s}$ broadened than that of Litoch. integra; the distance between the outer orbital angles is a little smaller in proportion to the width of the carapace, but, as in Litoch. integra, the breadth of the front is one-third that of the carapace. The whole animal, both the upper and the lower surface of the carapace and that of the ambulatory legs, is covered with a short close pubescence; like in Litoch. integra, the lateral margins of the carapace are fringed with longer hairs, a fringe of longer hairs exists on the front and the ambulatory legs are also furnished with longer hairs. In a lateral view the upper surface appears slightly curved downward on its anterior half and the front appears then vertically deflexed, the posterior half, however, flattened and the anterior half of the upper surface is but slightly declivous towards the antero-lateral borders. When the pubescence is removed, the semicircular groove that separates the gastric from the cardiac region, becomes-distinct, but the grooves separating the gastric region from the hepatic, the hepatic from the branchial and the cardiac from the intestinal regions, are hardly perceptible under a lens. A few granules occur near the antero-lateral margins, but for the rest the upper surface is smooth. 
The front (Fig. $2 b, 2 c$ ) is divided by a triangular notch into two rounded lobes that are obliquely directed backward; the emargination by which they are separated from the rounded internal angles of the orbits is hardly perceptible. There are probably two notches on the upper orbital margin and a few granules; the lower border of the orbits is smooth, has a small, triangular notch or hiatus just below the unarmed outer angle and the inner angle is rectangular, not prominent. The orbits are nearly half as broad or long as the front; the eyestalks, on which a few long hairs are implanted, appear distinctly broader on their proximal half than distally, when the carapace is looked at from before and in this view the angles which the front makes with the upper orbital margins, appear obtuse.

The antero-lateral margins of the carapace are but little shorter than the postero-lateral, measured to the coxae of the last pair of legs; they are divided (Fig. 2a) by three distinct triangular notches into four lobules. The first, including the outer orbital angle, is truncate and as long as the second, which is also truncate, the third is a little shorter than the preceding, more dentiform and more prominent, the fourth, finally, is very small and tuberculiform, the first and the second lobule bear each 4 or 5 granules, the third 2 or 3 . The postero-lateral margins are straight and converge but little backward, the posterior margin of the carapace, finally, is just as broad as the distance between the outer orbital angles.

The external antennae are about $4 \mathrm{~mm}$. long, a little longer than the width of the front, the flagellum measuring 2,8-2,9 $\mathrm{mm}$. On the endostome the posterior half only is ridged. Merus of the external maxillipeds quadrangular, a little broader than long, anterior border straight, antero-external angle slightly prominent, rounded, outer border a little concave, antero-internal angle emarginate for the insertion of the following joints; otherwise than in Litoch. integra the exognath reaches to the anterior margin of the merus. The subhepatic and pterygostomian regions are probably devoid of granules.

The 7-jointed abdomen (Fig. 2d) may be best recognized from the figure. The 7 th or terminal joint is obtusely rounded and just as long as broad at its base, the 6th is one-fourth shorter than the 7 th, its posterior margin one-fifth broader than the anterior, the 5 th and the $4^{\text {th }}$ are as long as the 6 th, but become gradually broader, the lateral margins of the 6 th -4 th are slightly concave; the 3rd is one-fifth shorter than the 4 th, but as broad as the 1 st, that occupies the whole width of the sternum between the last pair of legs; the 2 nd, finally, is a little shorter than the 3rd and but little broader than the $4^{\text {th }}$.

The ambulatory legs are rather slender and long, so e.g. are those of the penultimate pair $19 \mathrm{~mm}$. long, almost twice as long as the width of the carapace; the merus-joints are about 3-times as long as broad in the middle and unarmed, the dactyli, a little shorter than the propodi, end in a corneous claw which is a little curved upward.

Unfortunately I was unable to examine one of the four type specimens ( $3 \sigma^{\pi} \sigma^{\pi}, 1$ ㅇ with ova) from Singapore or Malacca, on which Litoch. subintegra was established by L a n chester, Mr. C. FORSTER COOPER, Superintendent of the University Museum of Zoology, Cambridge, having informed me that no specimens of Carcinoplax subinteger are in the Museum nor in the Catalogue. The identification is, however, certainly correct, because LANCHESTER has also examined the specimens from the Mergui Archipelago, described by me.

Litocheira subintegra (Lanch.) is still only known from Singapore or Malacca (LANCHESTER) and the Mergui Archipelago (DE MAN).

Litocheira splendida n. sp. (Pl. I, Fig. $3-3 c$, Pl II, Fig. $3 d-3 f$ ).

Two males and one female without eggs.

A new species of the same small size as Litoch. setosa (A. M.-Edw.) and Litoch. subintegra (Lanch.), the carapace of the largest specimen, a male, being $10 \mathrm{~mm}$. broad. In the two male specimens the carapace is little more than one-third, in the female almost once and a half as broad as long, so that Litoch. splendida also much agrees with those two species as regards the proportion between length and breadth. The upper surface of the carapace is flattened, both transversely and longitudinally, 
but anteriorly declivous towards the front which is almost vertically deflexed; like in the quoted species a transverse granulated row of long yellow hairs occurs on the front, a little behind the frontal border, with similar hairs the upper orbital and antero-lateral borders are fringed and shorter hairs are also implanted on the anterior third or fourth part of the upper surface; a short pubescence is observed on the postero-lateral borders, for the rest the upper surface of the carapace is glabrous, the lower also, except a fringe of hairs on the boundary between the subhepatic and subbranchial regions; the outer maxillipeds are partly pubescent, also the anterior end of the sternum and the lateral borders of the abdomen. The interregional grooves are more distinct than in the quoted species, they are, however, shallow, except the median part of the cervical groove between the gastric and the cardiac regions; the mesogastric area is well-defined, also anteriorly between the protogastric regions, and the intestinal region also.

The upper surface is smooth, except on the hepatic regions and on the anterior part of the gastric, though rather coarsely punctate, especially on the posterior half. Distance between the unarmed outer angles of the orbits little shorter than the length of the carapace, breadth of the front one-third that of the carapace; frontal border smooth, divided by a triangular notch into two rounded lobes, that are slightly emarginate near the obtuse lateral or supra-orbital angles, upper surface of the front also smooth. Both in Litoch. setosa and in Litoch. subintegra the frontal lobes show another form than in Litoch. splendida.

Otherwise than in Litoch. setosa, in which they are much shorter than the postero-lateral, but nearly as in Litoch. subintegra, the antero-lateral margins of the carapace are barely shorter than the postero-lateral, they pass. with a regular curve into one another. The antero-lateral margins $\mathrm{much}$ resemble those of Litoch. subintegra (Confer the figures $2 a$ and $3 a$ ), they are likewise divided by three notches in four sets of granules, of which the hindmost is formed by one granule, but the notches are less distinct than in LANCHESTER's species. The first or anterior set, including the outer orbital angle, is formed by five granules, that increase in size backward, on the second four, on the third three granules are observed. From the hindmost granule a curved row of granules runs inward, that separates the hepatic from the branchial regions, and between this row and the upper border of the orbits 20 or 25 granules are distributed on the hepatic region; immediately behind the already described, transverse row of granules, which is fringed with long yellow hairs, one observes on the front. at either side of the middle line another transverse row of 4 or 5 subacute granules that are also hairy, and between these granules and those of the hepatic region still other granules occur. All these granules are distinctly visible under the microscope, but for the naked eye the anterolateral borders of the carapace appear entire. Postero-lateral borders obtuse, little converging backward. The posterior margin of the carapace is slightly concave in the middle, a fine groove runs along its whole length.

Upper (Fig. $3 a$ ) and lower border of the orbits finely granulated, no hiatus near the outer angle, inner angle (Fig. $3 b$ ) rounded. Subhepatic and pterygostomian regions granulated, one or two larger granules on the former near the external orbital angle.

Second joint of the antennal peduncle reaching almost to the front, third joint a little shorter than the fourth or last. Epistome and anterior border of buccal cavern smooth, efferent branchial channels well-defined. Outer maxillipeds coarsely punctate, merus little broader than long, anteroexternal angle rounded, a little prominent, exognath reaching almost to the anterior border of the merus.

The abdomen occupies the whole width of the sternum between the last pair of legs and is 7-jointed. The abdomen of the male (Fig. 3d) differs from that (Fig. 2d) of Litoch. subintegra by the 4th to 7 th or terminal segment being more broadened; the reader is referred to these figures, but I will observe that the 7 th or terminal segment appears in Litoch. subintegra just as long as broad at its base, whereas in Litoch. splendida the posterior margin is one-third broader than the length, that in the $6^{\text {th }}$ segment the anterior margin is just as broad as the posterior with the lateral margins straight and parallel, whereas in Litoch. subintegra the anterior margin is distinctly less broad than the posterior and the lateral margins concave; in Litoch. subintegra, finally, the 
$4^{\text {th }}$ to $6^{\text {th }}$ segments have the same length, in Litoch. splendida the 6 th to the $4^{\text {th }} \mathrm{decrease}$ in length.

In the larger specimens of Litoch. subintegra, apparently the males, the pubescence which in the smaller specimens covers the palm of both chelipeds on the outer side, tends to disappear from below upwards in the right palm; leaving the upper margin, in the largest example, and the base of the palm still thickly covered, while the rest of the surface is naked, smooth, and of a white colour (W. F. Lanchester, in: Proc. Zool. Soc. London 1900, p. 751) - just as is the case also in Litoch. setosa (A. M.-Edw.).

The three specimens of Litoch. splendida bear each the two chelipeds. In the female they are equal and the whole outer surface of the palm is covered with pubescence and long silky hairs, but near the carpal articulation the lower border is smooth and glabrous; in the males the chelipeds are equal or subequal, the smooth glabrous part of the lower border near the carpal articulation is only a little larger, extending a little more upward, but, when looked at externally, the palm resembles that of the female. Merus short, trigonous, with a small blunt tooth near the distal end of the upper border, anterior margin finely denticulate on the distal half, inner margin hairy. Upper surface of the carpus (Fig. 3e) covered with subacute granules and hairy on its anterior, smooth on its posterior half, inner angle obtuse. The chelae present the same form and characters in both sexes, they are twice as long as the height of the palm, the dactylus is nearly twice as long as the upper border of the palm, but the fixed finger is nearly as long as the rest of the propodus, measured along the lower border; the outer surface of the palm is thickly covered with sharp granules; between which long silky, yellow hairs are implanted, except the smooth and glabrous area on and just above the proximal half of the lower border. On the slender tapering fingers that cross one another with their pointed curved tips, the sharp granules are arranged in longitudinal rows; a distal part of the fingers is of a dark purple colour, this distal part measured about one-third their length. The prehensile borders are armed along their whole length with teeth, which in the middle are larger. Inner surface of palm and fingers smooth, glabrous.

The ambulatory legs (Fig. 3 and $3 f$ ) are shorter and of a stouter shape than those of Litoch. subintegra, so are those of the penultimate pair a little more than once and a half as long as the carapace is broad; the merus of this pair is $2 \%$-times as long as broad. The legs of the penultimate pair of Litoch. subintegra, however, are almost twice as long as the carapace is broad, their merus is 3-times as long as broad in the middle. All the joints are unarmed, their surface smooth; these legs are, however, fringed with long yellow silky hairs on their margins, between which shorter occur; dactyli slender, terminating in a yellow claw.

Litoch. splendida is evidently also characterized by its splendid colouration. On a straw- or cream-coloured ground carapace and legs are adorned with pinkish or rosy flecks, that are symmetrically arranged; so the gastric region is pinkish coloured, but marked with small white spots, a crossshaped fleck covers the cardiac region, there is an oblique fleck on the anterior branchial region and several small rosy spots are on the hepatic area. The subhepatic and subbranchial regions show the same beautiful colour, the pterygostomian regions, the external maxillipeds, sternum and abdomen are white. In the legs of the last pair the distal half of the merus and the carpus are pink, on the other legs these rosy flecks are smaller.

Measurements in millimeters.

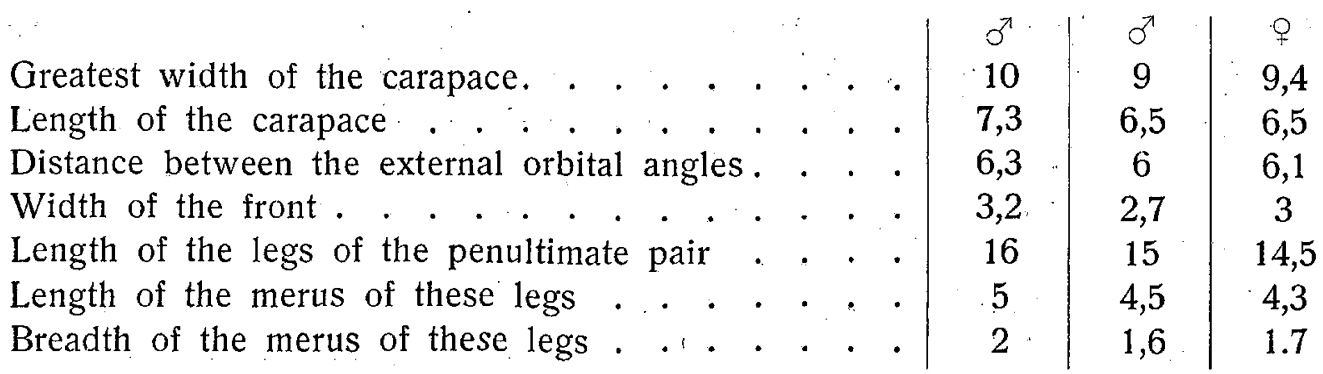


Litoch. subintegra (Lanch.), the nearest related species, differs from Litoch. splendida by the close short pubescence, with which the whole animal, carapace and legs, is covered, by the less distinct interregional grooves and the more distinct antero-lateral lobes of the carapace, by the different form of the abdomen, the longer and slenderer ambulatory legs and by the absence of the beautiful colouration.

$$
\text { Litocheira integra (Miers). (P1. II, Fig. 4-4g). }
$$

Carcinoplax integra E. J. Miers, in: Report Zoolog. Collections made in the Indo-Pacific Ocean during the Voyage of H. M. S. „Alert” 1881-2, London 1884, p. 543, P1. XLVIII, fig. C.

Litocheira integra L. A. Borradaile, in: The Fauna and Geography of the Maldive and Laccadive Archipelagoes, Vol. I, Part 4, 1903, p. 430.

Litochira integra E. L. Bouvier, in: Bull. Scientif. de la France et de la Belgique. Paris 1915, 7e Série, T. XLVIII, Fasc. 3, p. 119, fig. 34 .

Nec: Carcinoplax integer J. G. de Man, in: The Journal of the Linnean Soc. Zoology. London 1888, Vol. XXII, p. 93.

Nec: Litochira integra A. Alcock, 1. c. 1900, p. 314.

Confer J. J. TESCH, l. c. 1918, p. 176 (Siboga Monograph XXXIX $c^{1}$ ).

In order to identify with certainty the specimens of Litocheira from Pulau Berhala, that proved to belong to a new species, Litoch. splendida, it occurred to me that it should be necessary to become better acquainted with the nearest related forms, viz., Litoch. integra (Miers) and Litoch. subintegra (Lanch.). Upon my request Dr. BoRRADAILE of Cambridge courteously sent me for examination the only specimen, a female without eggs, which (1. c.) was rightly referred by him to Litoch. integra (Miers), I am moreover indebted to Dr. CaLman of the British Museum for a rough camera sketch of the type of Carcinoplax integra Miers.

The female from the reef at Hulule, Male Atoll, that sent me Dr. BorRadaile, has the same small size as the type from the Seychelles. The carapace (Fig. 4) is $5 \mathrm{~mm}$. broad, according to Dr. Calman that of the type $5,2 \mathrm{~mm}$., but, whereas in the latter according to the camera sketch the length is just two-thirds the breadth, the carapace is $2,85 \mathrm{~mm}$. long, the ratio between length and breadth being not 1,5 , but $1,75, \cdots$ so that the carapace appears a little broader. The external orbital angles that are unarmed, not at all prominent, are 3,6 $\mathrm{mm}$. distant from one another and the front is anteriorly $1,6 \mathrm{~mm}$. broad, one-third the breadth of the carapace. Looked at from above (Fig. 4a), the front which is a little deflexed and notched in the middle, presenting here a triangular notch (Fig. 4b), projects in the middle more forward than laterally; the smooth, anterior margin of the front runs from the middle straight and obliquely backward and curves regularly into the lateral borders; when, however, the front is looked at from before (Fig. 4d), the frontal lobes appear laterally slightly emarginate.

I observe under the microscope on the upper surface of the carapace which is covered with a short close pubescence, a trace of a shallow semicircular groove, that separates the gastric from the cardiac region, perhaps also a trace of the mesogastric groove, but other grooves were not observed. The lateral margins of the carapace are regularly arched, the antero-lateral much shorter, barely half as long as the postero-lateral, that are a little curved and much converge backward; to the naked eye the antero-lateral borders appear entire, under the microscope, however, they appear finely granulated (Fig. $4 c$ ), presenting 12 or 13 very small, subacute granules of somewhat unequal size, but no notches; the hindmost granule, situated there where the antero-lateral margins pass into the posterolateral, is a trifle larger than the rest and from this tooth a short transverse line of short hairs runs inward. The postero-lateral borders are also finely granular, at least anteriorly. On the hepatic region 5 or 6 small granules were observed, a few also, of unequal size, near the concave posterior margin and perhaps there are also a few microscopical granules on the rest of the upper surface. At a distance of $0,3 \mathrm{~mm}$. from the frontal border a transverse row of long hairs are implanted on the front and with similar hairs the lateral borders of the carapace and the upper borders of the orbits are fringed. The orbits are nearly half as broad as-the front, the lower border (Fig. 4d) is finely granulated, the upper probably also, but without fissures or notches, the lower border projects a little forward in the middle, the inner angle is rounded. 
When the carapace is looked at from before (Fig. $4 d$ ), the globular terminal part of the eyestalks appears a little shorter than the less broad rest of the peduncle; when, however, the front is looked at from above (Fig. $4 a$ ) the proximal half of the peduncle appears much broadened and broader than the distal part; cornea yellow-brown, but black interiorly, when seen under the microscope.

The eyestalks bear several feathered hairs.

The external antennae are $2,1 \mathrm{~mm}$. long, one-third longer than the breadth of the front; the basal joint (or actual second) that Dr CALMAN supposes to be formed by the coalescence of the 2nd and 3rd joint (W. T. Calman, A Treatise on Zoology, London 1909, p. 258, Fig. 147 B and C) of the peduncle, extends almost to the front (Fig. $4 d$ ), the two following are much less broad and the terminal joint is a little shorter than the penultimate; the flagellum, 1,4 mm. long, is composed of

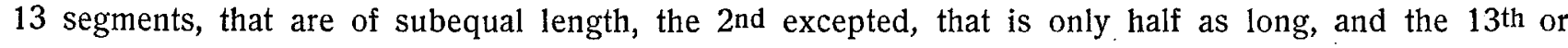
last, which is a little longer than the preceding and furnished with 2 or 3 long setae on the tip.

Between the antero-external angle of the buccal frame and the transverse first joint of the antennal peduncle is situated a white coloured transverse piece, the anterior border of which is concave and that laterally ends in a sharp tooth. Merus of the external maxillipeds $0,52 \mathrm{~mm}$. broad, $0,46 \mathrm{~mm}$. long, subquadrate, a litile broader than long; the antero-external angle is rounded, the antero-internal concave. Width of the exognath nearly one-third that of the merus. The chelipeds are subequal, thickly pubescent and hairy; merus short and trigonous, with a small blunt tooth or lobe near the distal end of the upper margin, antero-internal border of ischium and merus armed with sharp conical granules, antero-external also granular. Carpus somewhat angulated on its inner border, with one or two subacute granules at the angle, some sharp granules on the wrist of the smaller cheliped. The shape of the chela may be best conceived from the figure $4 e$; lower border concave, fingers a little longer than the upper border of the palm. The outer and upper surface of the palm is covered with small subacute granules, that show a tendency to be arranged in longitudinal lines, on the fingers, however, the granules are distinctly arranged in such longitudinal rows. The fingers (Fig. $4 f$ ) shut close together, their pointed tips cross one another and their prehensile borders bear along their whole length 5 or 6 conical teeth.

The specimen bears, besides the chelipeds, only the right leg of the $5^{\text {th }}$ pair (Fig. $4 g$ ), which is about twice as long as the carapace; merus nearly 3-times as long as broad, dactylus $1,3 \mathrm{~mm}$. long, ending in a small corneous claw. This leg is covered with a short close pubescence, formed by short feathered hairs and fringed moreover with long simple hairs.

The specimen has a grayish colour, while the lateral parts of the upper surface of the carapace have a pale pinkish tinge.

The male from the Mauritius, described by Bouvier, appears to belong to this species; the carapace, $5 \mathrm{~mm}$. broad, should be $4 \mathrm{~mm}$. long, but the abdomen is, no doubt, counted in; the ambulatory legs were granular above.

Pinnotheres palaensis Bürger. (Pl. II, Fig. 5-5b).

Pinnotheres palaensis O. Bürger, Ein Beitrag zur Kenntniss der Pinnotherinen, in : Zoolog. Jahrb. Abth. f. Syst. Bd. VIII, Jena 1894-95, p. 372, Taf. 9, fig. 12 and Taf. 10, fig. 12.

Pinnotheres palaensis J. J. Tesch, The Decapoda Brachyura of the Siboga Expedition. II. Goneplacidae and Pinnotheridae. Leiden 1918, p. 249 and 254 (Monographe XXXIX $c^{1}$ ).

Confer: J. G. DE MAN, Sur quelques anomalies observées chez deux espèces du genre Pinnotheres Latr. de 1'Archipel Indien. Paris, Londres 1921, p. 262-265, Pl. VIII, fig. 8-14 (Bulletin Biolog. France et Belgique, T. LV, fascicule 2).

Seven full-grown, ova-bearing and four very young females and two males, collected by Mr. Spennemann at Indramajoe (Java) from shells of Arca granosa.

In my quoted paper of 1921 the singular fact has been described that both in a specimen of Pinnotheres arcophilus Bürger from Lombok and in one of Pinn. palaensis Bürger from Amboina the two legs of the penultimate pair, i.e. of the 3 rd pair of ambulatory legs, were unequal, the joints, especially the propodus and the dactylus, presenting great differences in length and breadth. In both specimens it was the left leg of the penultimate pair that was abnormal. The two individuals 
were each infested by a parasitic Isopod, belonging to the Bopyridae, but Professor PÉREZ of the Sorbonne, who had sent me these specimens, did not ascribe these abnormalities in the legs to the parasitism of the Bopyridae, for he wrote me the following: „Pour les anomalies que vous me signalez, je ne pense pas qu'elles puissent être imputées à la présence des parasites, car l'action morphogène de ces parasites ne se manifeste généralement que dans les caractères sexuels seconḍaires." (J. G. DE MAN, 1. c. p. 264). I myself considering that the left abnormal leg of the specimen from Lombok presented a great resemblance to the right normal leg of the penultimate pair in the other specimen and the left abnormal leg of the latter a great resemblance to the right normal leg of the former, was led to the supposition that the abnormalities were owing to a cross-breeding of the two species that both occur in Arca.

The 13 specimens from Indramajoe, no one of which is infested by a parasite, but that all look quite healthy, show all just the same abnormalities as the two, déscribed in 1921: in all the specimens indeed the joints of the right leg of the penultimate pair show other measurements than those of the left, but otherwise than in the two specimens, described in 1921, it is not always the left leg the measurements of which are abnormal.

In Pinn. palaensis the dactyli of the legs of the penultimate and of the last pair are considerably longer than those of the two preceding pairs, they have nearly the same length and are described by BÜRGER as about 3-times as long as those of the antepenultimate pair. As results from the Table of measurements, in six of the seven measured females the right leg of the penultimate pair shows the normal measurements characteristic of Pinn. palaensis, but in $\mathrm{N}^{\prime \prime} 6$ the right leg appears the shorter, instead of the left; of the two males in one the left, in the other the right leg is the shorter.

When we, however, consider the shorter leg of the penultimate pair as presenting the normal characters of the species, then this species should be referred to Pinn. arcophilus Bürger or to Pinn. modiolicola Bürger. In Pinn. arcophilus, however, the dactylus of the external maxillipeds does by far not reach to the end of the propodus (J. G. DE MAN, 1.c. fig. 1a), the dactylus being just as long as the distance between its tip and that of the propodus, which in the species from Indramajoe is not the case (Fig. 5 and $5 a$ ); as regards Pinn. modiolicola, in this species the palm of the anterior legs is barely one and a half times as long as high, in the adult females from Indramajoe, however, more than twice; in young females the chela is comparatively higher, so in a female of which the carapace is $5,5 \mathrm{~mm}$. long, the palm is $1 / 1 / 2$-times as long as high (Fig. $5 b$ ). Also in other characters the specimens agree with Pinn. palaensis, the carapace resembles fig. 12 on Plate 9 of BÜRGER's paper, but the posterior margin is distinctly concave, though not so much as in Pinn. Maindroni Nobili from Obock.

Table of measurements in milimeters.

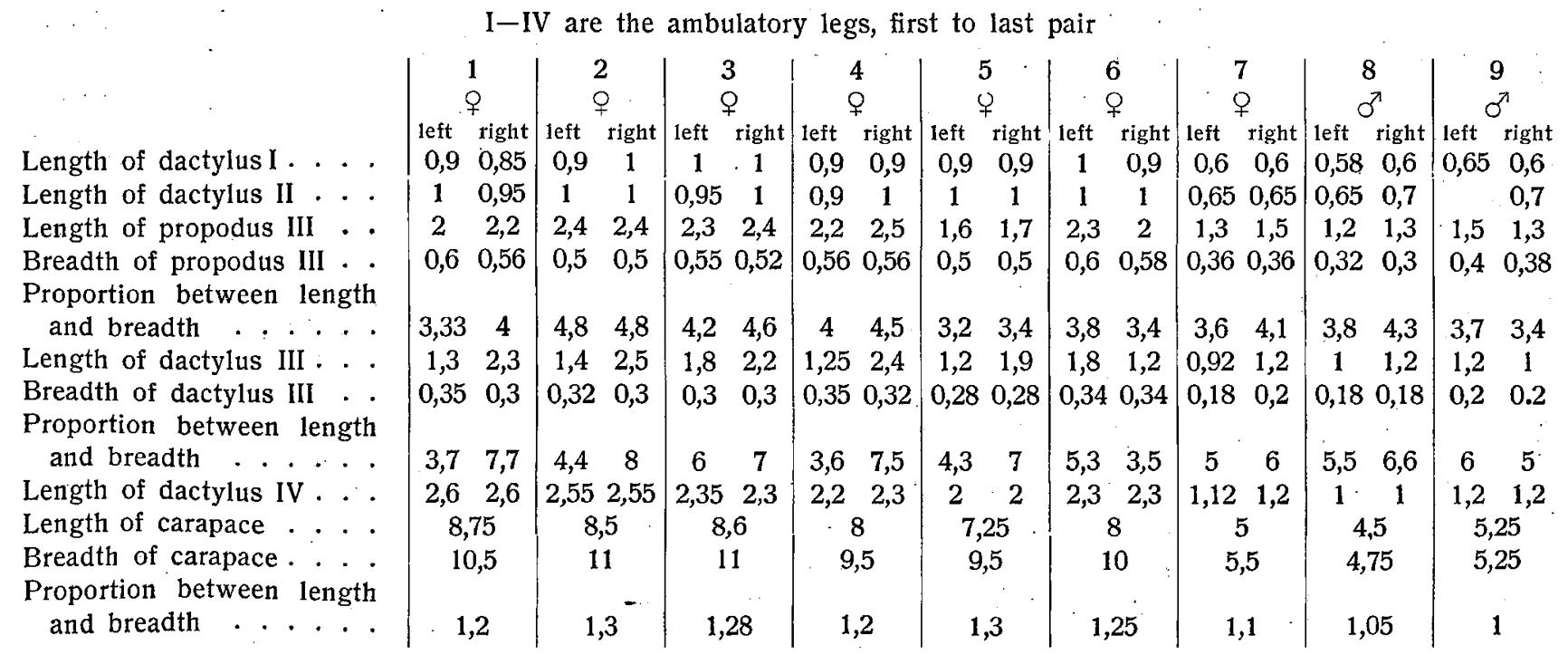

The female $\mathrm{N}^{0} 7$ bears no eggs. 
The proportion between length and breadth of the carapace varies from $1,25-1,3$, while, according to Dr. Tesch (1.c. p. 254), Pinn. palaensis should belong to those species in which the carapace is at most 1,2-times as broad as long: in my opinion should this character not be used for distinguishing sections of this genus from one another. The largest females are $11 \mathrm{~mm}$. broad and $8,5 \mathrm{~mm}$. long, the larger male $5,3 \mathrm{~mm}$. broad, $5 \mathrm{~mm}$. long.

Prof. PÉREZ proves thus to have been right when he did not impute to parasitism the singular fact of the dissimilarity of the legs of the penultimate pair; when this dissimilarity should, however, be caused by cross-breeding, it remains inexplicable why only this pair is affected. This dissimilarity will perhaps once prove to be a constant character not only of this, but also of other species of Pinnotheres.

\section{Ocypoda ceratophthalma (Pallas).}

Ocypoda ceratophthalma (Pallas), A. Alcock, 1. c. 1900, p. 345.

Three adult and four young males.

In the largest specimen the distance between the external orbital angles measures $42 \mathrm{~mm}$. Either the right or the left cheliped is the larger.

\section{Grapsus gracilipes H. M.-Edw. (Pl. III, Fig. 6-6f and Fig. 7).}

Grapsus gracilipes H. Milne Edwards, in: Annal. Scienc. Naturelles (3). Zoologie. T. XX, Paris 1853, p. 168 (134).

Grapsus gracilipes J. G. de Man, in: Notes from the Leyden Museum. Vol. V, Leiden 1883, p. 159 and in:

Abhandl. d. Senckenb. Naturf. Gesellschaft, Bd. XXV, Frankfurt am Main 1902, p. 502.

Grapsus gracilipes A. Sendler, in: Abhandl. d. Senckenb. Naturf. Gesellschaft, Bd. XXXVIII, Heft 1, Frankfurt am Main 1923, p. 31.

Two well-preserved males, one of which is full-grown.

Of this species the first short description or rather diagnosis was published by $\mathrm{H}$. MILNE EDWARDS in 1853 that reads thus :

„Cette espèce se distingue de toutes les précédentes (Grapsus maculatus (Catesby), Webbi H. M.-Edw., ornatus H. M.-Edw., rudis H. M.-Edw. and Pharaonis H. M.-Edw.) par la forme grêle et allongée de ses pattes, et par le peu de saillie des lobules protogastriques, disposition qui rend la région frontale oblique, au lieu d'être verticale comme d'ordinaire. La carapace est garnie de petites soies roides, comme chez le G. rudex. - Mers de Chine, Taoranne". Figures were not published.

In 1883 when I was still a keeper at the Natural History Museum at Leiden, a young male from Amboina was referred by me to this species and in 1902 a full-grown female without eggs from Ternate (locis citatis).

In her valuable work "The Brachyura and Macrura of the Hawaiian Islands. Wash. 1906, p. 838" Miss Dr. Rathbun has pointed out that „the common rock crab of the tropics, Grapsus grapsus, is separable into two forms, one in which the lobe on the wrist is very broad and terminates in a short point ( $G$. grapsus typical) and one in which the same lobe is narrow and terminates in a long narrow spine (tenuicrustatus Herbst). The former inhabits the coasts of America, including the outlying islands, such as the Galapagos, and also the eastern shores and islands of the Atlantic Ocean; the latter is restricted to the oriental region". Miss RathBun does not speak, however, about Grapsus gracilipes, which is nearer related to her subspecies tenuicrustatus than to the typical G. grapsus.

In order therefore to become still better acquainted with the differential characters of these species I applied to the Direction of the National History Museum at Leiden, which very kindly intrusted to me the following specimens, for which help I tender my sincere thanks:

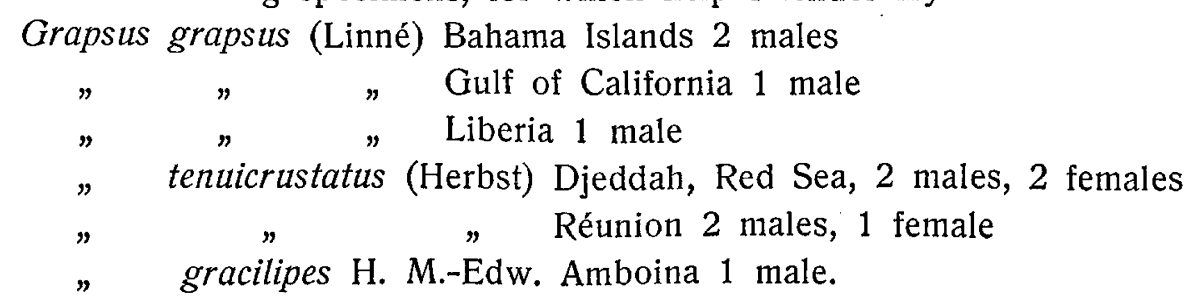


Moreover are lying before me a male and a female of Grapsus tenuicrustatus (Herbst) from Pontianak, west coast of Borneo, specimens that were described by me in 1895 in: Zoolog. Jahrb. IX Abth. f. Syst. p. 79 and that belong to my private collection.

Of all these specimens and of the males from Berhala the measurements are indicated in the Table excepting a young male and female from Djeddah and a young male from Réunion.

A thorough examination led me to the conclusion that indeed three species are to be distinguished.

Both in Gr. gracilipes and in Gr. tenuicrustatus the width of the front, measured along the line of flexion, is just half as long as the distance between the external orbital angles, in $G r$. grapsus, however, constantly a little longer; this fact was already observed by H. MILNE EDwARDS and RANDALl who in their descriptions of Gr. rudis H. M.-Edw. and Gr. hirtus Rand., species that are identical with one another and with Gr. tenuicrustatus, describe the front as narrower than in the american form, (H. Milne Edwards, 1. c., J. W. Randall, in: Journal of the Acad. of Nat. Sciences of Philadelphia, Vol. VIII, Part I, Philadelphia 1839, p. 124). Randall moreover adds that the front is rather more produced, while MILNE EDWARDS in his description of Gr. gracilipes remarks "le peu de saillie des lobules protogastriques, disposition qui rend la région frontale oblique, au lieu d'être verticale comme d'ordinaire". In a lateral view of the carapace the front proves to be vertically deflexed in all the three species; in the american species the four frontal lobes are prominent, placed nearly in a transverse line and separated from one another by small shallow incisions, so that only little of the deflexed part of the front is visible when the carapace is looked at from above; in the male from Liberia, that has the same size as the larger male from the Bahamas, the median frontal lobes are also transverse, but are placed a little more backward, so that a greater part of the front is visible; this is still more the case in the indo-pacific specimens of $G r$. tenuicrustatus and gracilipes, and the interlobular incisions, especially the median one, are here $\mathrm{much}$ larger and deeper (Fig. 6, 6a) than in Gr. grapsus; in these indo-pacific specimens a much larger part of the front is therefore visible and the front appears oblique when the carapace is looked at from above. The length of the carapace, its greatest width and the distance between the external orbital angles present in the three species the same proportions.

Both in the full-grown male of $G r$. gracilipes from Berhala and in the much younger male of the same species from Amboina, the specimen that I have described in 1883, the length of the penultimate segment (Fig. 6c) of the abdomen is just half as long as the posterior margin, in the two other species, however, the penultimate segment is a little longer than half the width of the posterior margin, so that in Gr. gracilipes this segment appears slightly broader than in the two others.

Very characteristic is the form of the lobe at the inner angle of the wrist of the chelipeds; this character, used by Miss RATHBUN for distinguishing Gr. grapsus from Gr. tenuicrustatus, was already observed by $\mathrm{H}$. MILNE EDWARDS and RANDALl (locis citatis) in their species Gr. rudis and Gr. hirtus. In the full-grown male of Gr. grapsus from California this lobe is $8 \mathrm{~mm}$. long, $6 \mathrm{~mm}$. broad; ends in a short point that is only $1 \mathrm{~mm}$. long and has the same broad form as in the specimens from the Bahamas (Fig. 7) and Liberia; in the full-grown male of Gr. gracilipes from Pulau Berhala this lobe (Fig. $6 d$ ) that has the same form as in Gr. tenuicrustatus, is $6 \mathrm{~mm}$. long, 2,75 mm. broad, not yet half as broad as long and terminates in a spine, which, $2 \mathrm{~mm}$. long, measures one-third the whole length of the lobe.

The chief difference between Gr. tenuicrustatus and Gr. gracilipes is shown by the ambulatory legs which in the latter (Fig. $6 e, 6 f$ ) are longer and more slender than in HERBST's species, a difference more conspicuous, however, in old than in young individuals (confer the Table of measurements); in adult specimens of both species 2 or 3 small rudimentary teeth are observed at the distal extremity of the posterior margin of the 5th legs, in the young male from Amboina, the carapace of which is $37 \mathrm{~mm}$. broad, there is a small rudimentary tooth at that distal extremity and in the female from Ternate, described by me in 1902 (1. c.), in which the carapace was $38 \mathrm{~mm}$. long, already 3 or 4 small teeth were observed, but in a specimen $\left(\mathrm{N}^{0} 9\right)$ of Gr. tenuicrustatus of which the carapace is even 
$46 \mathrm{~mm}$. broad and $42,5 \mathrm{~mm}$. long, the merus of the 5th legs is still rounded, without a trace of a tooth.

In the three young specimens of Réunion, in the largest of which the carapace is only $36 \mathrm{~mm}$. broad, the distal extremity of the merus of the 5th legs is also still rounded.

$G r$. Pharaonis, a species identical with Gr. tenuicrustatus, was distinguished by H. MILNE EDWARDS (1. c.) by the merus of the 5th legs being rounded at its lower distal extremity, in the larger male from Djeddah, however, $\left(\mathrm{N}^{0} 8\right.$ of the Table) the merus of the right fifth leg bears 3 small acute teeth at the lower distal end, while the merus of the left is still unarmed. These observations seem to prove that in Gr. gracilipes these small teeth on the merus of the 5th legs appear at a younger age than in $G r$. tenuicrustatus, but further observations are needful for confirming this supposition. The carapace of the adult male from Djeddah $\left(\mathrm{N}^{0} 8\right.$ of the Table) is just as broad $(60 \mathrm{~mm}$.) as that of the full-grown male of Gr. gracilipes from Pulau Berhala, in the former the ambulatory legs of the penultimate pair are, however, $15 \mathrm{~mm}$. shorter than in the latter.

VON MARTENS has communicated that one of HERBST's type specimens was collected at Tranquebar (in: Archiv f. Naturgeschichte. Jahrg. XXXVIII 1872, p. 107) and Dr. HILGendorf who in 1878 had again occasion to study them, supposed these type specimens to belong to two different species, apparently on account of the absence or presence of the small teeth on the lower distal extremity of the merus of the 5th legs (F. Hilgendorf, in: Monatsber. Kön. Akad. Wiss. Berlin, 1878, p. 807). Unfortunately, as Prof. A. SCHELlenberg kindly informed me, Herbst's type specimens of Cancer tenuicrustatus (J. F. W. HeRBST, Krabben und Krebse, I, p. 113, Tab. III, fig. 33, 34) exist no more; Prof. Schellenberg supposes these old broken dry specimens to be thrown away during the great war, when the collections of the Museum were transported to the new building.

The full-grown male from Pulau Berhala has a colour red as wine, darker on the carapace than on the legs, the whole animal, carapace and legs, is marked with a great number of small yellow spots: probably, however, these specimens will prove to show a different colouration when alive.

With certainty Grapsus gracilipes H. M.-Edw. is at present known from the Chinese Seas, Taoranne (H. Milne EdwARds), Pulau Berhala, Amboina and Ternate (DE MAN), Makatea, Paumotu Archipelago (SENDLER).

Table of measurements in millimeters.

\begin{tabular}{|c|c|c|c|c|c|c|c|c|c|c|c|c|c|}
\hline & $\begin{array}{l}0^{7} \\
1\end{array}$ & $\begin{array}{l}0^{\nearrow} \\
2\end{array}$ & $\begin{array}{l}0^{7} \\
\mathbf{3}\end{array}$ & $\begin{array}{l}0^{7} \\
4\end{array}$ & $\begin{array}{l}0^{7} \\
5\end{array}$ & $\begin{array}{l}0^{7} \\
6\end{array}$ & $\begin{array}{l}\sigma^{7} \\
7\end{array}$ & $\begin{array}{l}0^{7} \\
8\end{array}$ & $\begin{array}{l}q \\
9\end{array}$ & $\begin{array}{l}0^{\pi} \\
10\end{array}$ & $\begin{array}{l}q \\
11\end{array}$ & $\begin{array}{c}0^{7} \\
12\end{array}$ & $\begin{array}{c}\text { 9 } \\
13\end{array}$ \\
\hline istance between the extern & 44,3 & 31 & 26,7 & 40 & 33 & 45,5 & 37 & 42,3 & 33,3 & 24 & 26,5 & 34 & 30 \\
\hline 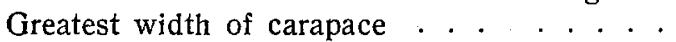 & 60 & 41,5 & 37 & 57 & 45 & 72 & 54,5 & 60 & 46 & 31,25 & 36 & 46,5 & \\
\hline midline . . . . . & 56 & & 33,5 & 52 & 40 & 64 & 8,5 & 55 & 42,5 & 28 & 32,5 & 44 & ט, \\
\hline of the outer lobes & 22,5 & 5 & 13,25 & 22 & 17,25 & 28 & 9,5 & 22 & 17 & 12 & 13 & 17 & 4,5 \\
\hline er of the carapace. & 18,5 & 16 & 13,5 & 19 & 17 & 23 & 18,5 & 20,5 & 19 & 12,5 & 16 & 17.5 & \\
\hline me. & 16,5 & 12 & 9,5 & 16,5 & 13 & 20 & 14,5 & 16,5 & 13,5 & 9 & 10 & 13 & \\
\hline en & 5 & 3,1 & 2,5 & 4 & 3 & 5 & 3,5 & 4,25 & 3 & 1,75 & 2 & 3,5 & \\
\hline.. & 7 & 5,4 & 4, & 7,5 & 6 & 8 & 6,75 & 7,5 & & 4,3 & & b & \\
\hline en & 8,5 & 7 & 5,5 & 7 & 6,25 & 7,5 & & 8 & & 4,3 & & 6,5 & \\
\hline & 14 & 10,5 & 9 & 12,25 & 10,75 & 15 & 11,5 & 14 & & 7 & & 11,5 & \\
\hline e & 135 & 100 & 89 & 120 & 100 & 132 & 114 & 122 & 100 & 63 & 80 & & \\
\hline Len & 45 & 34 & 29 & 40 & 34 & 40 & 37 & 39,5 & 32 & 20,5 & 27 & 34 & 31 \\
\hline or tile pertutinate & 15,5 & 12,5 & 10,5 & 17 & 14,25 & 18,5 & 15,3 & 16,5 & 13,5 & 8 & 11,25 & 14,5 & 12,3 \\
\hline h of the propodus & 37 & 28 & 24 & 31 & 27 & 32 & 30 & 32 & 26 & 16,5 & 21. & & 26 \\
\hline Wid & 6,7 & 5 & 4 & 7 & 5,7 & 9,3 & 6,5 & 8 & & 3,5 & 4,75 & & 5,25 \\
\hline$r$ of $a m b$ & 110 & 81 & 69 & 9 & 80 & 120 & 91 & 102 & 78 & 57 & 59 & & 5 \\
\hline & 34 & 26 & 22 & 31 & 25 & 37 & 29 & 32 & 24 & 19 & 19 & 26,5 & 23 \\
\hline Width of the merus (of the last pair of & 14,25 & I1 & 9,25 & 14 & 11,5 & 17 & 13,5 & 15 & 11,75 & 8 & 8,75 & 12,5 & 10,5 \\
\hline Length of the propodus $\quad$ legs & 30,5 & 22 & 19 & 25 & 21 & 30 & 24 & 26 & 21 & 15,5 & 15 & & 21 \\
\hline Width of the propodus & 7,3 & 5 & 4,25 & 7,3 & 6 & 9,5 & 7 & 8 & 6 & 3,75 & 4,3 & & 5,5 \\
\hline
\end{tabular}

$\mathrm{N}^{0} 1$ and 2 Grapsus gracilipes H. M.-Edw. Pulau Berhala.

$\mathrm{N}^{0} 3$ Grapsus gracilipes H. M.-Edw. Amboina.

$\mathrm{N}^{0} 4-7$ Grapsus grapsus (Linné). $\mathrm{N}^{0} 4$ and 5 Bahama Islands, $\mathrm{N}^{0} 6$ California; $\mathrm{N}^{0} 7$ Liberia.

$\mathrm{N}^{0}$ 8-13 Grapsus tenuicrustatus (Herbst). $\mathrm{N}^{0} 8$ and 9 Djeddah, Red Sea; $\mathrm{N}^{0} 10$ and 11 Réunion, $\mathrm{N}^{0} 12$ and 13 Pontianak. 


\section{Grapsus strigosus (Herbst).}

Grapsus strigosus (Herbst), A. Alcock, 1. c. 1900, p. 393.

One male and one egg-bearing female.

The carapace of the male is $41,5 \mathrm{~mm}$. broad, that of the female $34,5 \mathrm{~mm}$. The lateral margins of the antepenultimate segment of the male abdomen are quite straight, in a male of the same size from Pontianak (private collection) they are distinctly concave. In the male from Pulau Berhala the merus of the penultimate pair of legs is $30 \mathrm{~mm}$. long, $12,7 \mathrm{~mm}$. broad.

\section{Varuna litterata (Fabr.).}

Varuna litterata (Fabr.), A. Alcock, 1. c. 1900, p. 401.

Two males and one egg-bearing female.

The greatest breadth of the carapace, measured at the last pair of antero-lateral teeth, is in the larger male $34 \mathrm{~mm}$., in the other male $27 \mathrm{~mm}$. and in the ova-bearing female $25 \mathrm{~mm}$.

\section{Sesarma (Sesarma) ocypoda Nobili.}

Sesarma ocypoda G. Nobili, in: Annali del Museo Civico di Storia Naturale di Genova, Serie $2 a$, Vol. XX (XL) 1900 , p. 513.

Sesarma ocypoda J. G. de Man, in: Abhandl. Senckenb. Naturf. Gesellschaft. Bd. XXV. Frankfurt am Main 1902 , p. 525, Taf. XIX, fig. $10-10 d$.

Sesarma ocypoda J. J. Tesch, in: Zoolog. Mededeelingen uitgegeven vanwege 's Rijks Museum v. Nat. Hist. te Leiden, 1917, Deel III, p. 179 and 245.

Five males and six females, two of which are ova-bearing; these specimens were collected in August 1927 under stones and roots in the two fresh-water brooklets of Pulau Berhala.

In the largest male the distance between the external orbital angles is $9,5 \mathrm{~mm}$. broad, this specimen is full-grown and presents the same measurements as the only type described by NoBILI (J. G. DE MAN, 1.c. p. 526). The red coloured chelipeds of this male are equal; the ridge on the upper border of the dactylus is quite distinct and extends from the tip to a little beyond the middle; at the inner side of the ridge one observes the row of 9 acute teeth that reach from the base to near the tip of the finger and the sharp tips of which are all directed forward; from the 1 st at the base of the finger these teeth grow gradually larger until the 4th and the 5th that are the largest, the following become gradually smaller. In another male of the same size the right cheliped is much smaller than the left, in both the upper border of the dactylus bears 9 teeth, this inequality is no doubt abnormal; in the three other younger males the chelipeds are equal and the upper border of the dactylus bears in all also 9 teeth. In the type specimen from Benkoelen the upper border of the dactylus bears 13 to 15 teeth, while in the male of Ses. sylvicola de Man, which inhabits the forest near Muka-Muka at Manindjau, Sumatra, only 6 or 7 teeth occur, that also reach to the tip. The specimens from Pulau Berhala form, as regards the number of these teeth, a transition between the two forms and I should not be surprised that both will once prove to be one and the same, species. In all the specimens from Pulau Berhala, however, the distance between the first epibranchial teeth is less broad than that between the more or less acute, extraorbital angles.

In the two egg-bearing females the distance between the external orbital angles measures 9 , respectively $8 \mathrm{~mm}$., so that they have the same size as the adult male; each female is provided with 13 eggs of large size, their diameter being $1,3-1,4 \mathrm{~mm}$. broad.

The ambulatory legs show the same red colour as the chelipeds, the upper surface of the carapace is of a darker red.

The young male specimen of Ses. aranea Nobili, with which I have dealt in my description of Ses. thelxinoë (J. G. de Man, in: Records of the Indian Museum, Vol. II, Part II, Calcutta 1908, p. 184), is lying again before me. Ses. aranea differs from Ses. ocypoda Nobili at first sight by the much finer granulated anterior part of the upper surface of the carapace, by the outer post-frontal lobes being 
only half as broad as the inner, while in Ses. ocypoda the outer measure about two-thirds of the inner and by the lower border of the front being nearly straight; there are, however, still more differences. As Mr. VAN DER MEer MoHr wrote on the label the carapace of Ses. ocypoda is in life of a dark gray brown colour, the chelae bright red.

\section{Metasesarma Rousseauxi H. M.-Edw.}

Metasesarma Rousseauxi H. M.-Edw., A. Alcock, 1. c. 1900, p. 427.

One young male collected 8th August 1927 on a tree-trunk that was fallen down, above highwatermark. The greatest breadth of the carapace is $8,7 \mathrm{~mm}$., the length $8 \mathrm{~mm}$., the distance between the external orbital angles $8,6 \mathrm{~mm}$., width of the front $5 \mathrm{~mm}$., width of the posterior margin $4,2 \mathrm{~mm}$.

\section{Gecarcoidea Lalandii H. M.-Edw.}

Gecarcoidea Latandii H. Milne Edwards, Hist. Nat. Crustacés, T. II, 1837, p. 25.

Gecarcoidea Lalandii M. J. Rathbun, The Grapsoid Crabs of America. Wash. 1917, p. 364, Pl. 160, figs. 7 and 8 (Smithsonian Institution. United States National Museum, Bulletin 97) (ubi literatura).

Four full-grown males and two adult females without eggs.

In the male $\mathrm{N}^{0} 3$ of the Table of measurements one observes on the middle of the mesogastric region at either side a small tubercle, these two tubercles, $5 \mathrm{~mm}$. distant from one another, arise, however, hardly above the surface; in the other specimens they are invisible. In the larger female there is at a distance of $2,5 \mathrm{~mm}$. from the outer orbital angle a low subacute tubercle from which a finely granulated line, long 8 or $10 \mathrm{~mm}$., runs laterally outward, separating the pterygostomian region from the upper surface, and just behind it, at the anterior extremity of the groove defining the protogastric region, an oval depression long 4 or $5 \mathrm{~mm}$., apparently for the insertion of a muscle; in the other female the granulated line and the depression exist also, but the tubercle is not yet developed. In the males that muscular depression exists, of course, likewise; in the youngest male $\left(N^{0} 4\right)$ the granulated line with a trace of the low tubercle is observed nearly as in the female $\mathrm{N}^{0} 5$, but in the other males the tubercle is wanting and the transverse line smooth.

In the larger female the tooth or lobe at the inner lower angle of the orbits joins the angle of the front, so that the antennae are excluded from the orbits; in the other female there is an interspace, $1 \mathrm{~mm}$. broad, between the tooth and the front, in the youngest male the tooth also meets the front, though not so broadly as in the female $\mathrm{N}^{0} 5$, in the three other males the front and the tooth are separated by an interspace $0,4-0,6 \mathrm{~mm}$. broad.

In all the male specimens and in the younger female the right cheliped is the larger, in the two largest males $\mathrm{N}^{\prime \prime} 1$ and 2 and in the younger female the chelipeds are unequal, in the other specimens equal or nearly so. In the larger chela of the male $\mathrm{N}^{0} 1$ the dactylus, $65 \mathrm{~mm}$. long, is

Measurements of the six specimens in millimeters.

\begin{tabular}{|c|c|c|c|c|c|c|}
\hline & 1 & 2 & $\begin{array}{l}3 \\
0^{\pi}\end{array}$ & 4 & 5 & 6 \\
\hline Distance between the external orbital angles . . . . & 39 & 39 & 39 & 33 & 35,5 & 33,5 \\
\hline Greatest breadth of the carapace . . . . . . & 117 & 113 & 110 & 88 & 98 & 88 \\
\hline Length of the carapace . . . . . . . & 81 & 80 & 75 & 62 & 70 & 66 \\
\hline Width of the anterior border of the front & 16 & 16 & 16 & 13 & 15,5 & 14 \\
\hline Greatest breadth of the orbit ..... & 13 & 13 & 13 & 10,5 & 11,5 & 11 \\
\hline ae orbit, measured to the level of the anterior border of the front & 9 & 9 & 9,5 & 8,5 & 9 & \\
\hline 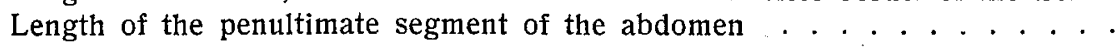 & 13 & 13 & 13 & 10,5 & 15,5 & 15,5 \\
\hline readth of the anterior margin of this segment. . . . . . & 11,5 & 11,5 & 11,5 & 9,5 & 21,5 & 21 \\
\hline Breadth of the posterior margin of this segment . & 24 & 23,5 & 22 & 18,5 & 53,5 & 48 \\
\hline 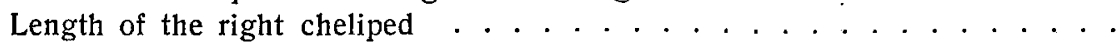 & 230 & 230 & 200 & 135 & 140 & 125 \\
\hline easured in the middle... & 58 & 60 & 55 & 45 & 34 & 32 \\
\hline eight of this chela at the distal end of the upper border :... & 37 & 41 & 38 & 33 & 24 & 22,5 \\
\hline
\end{tabular}


almost twice as long as the upper border, long $35 \mathrm{~mm}$., of the palm, in the smaller chela these numbers are in the same succession $48 \mathrm{~mm}$. and $30 \mathrm{~mm}$; the fixed finger of the larger chela is armed along its whole length with 25 or 26 teeth, of which the 7 distal ones are smaller than the preceding and contiguous, while the preceding teeth are separated by small interspaces; the dactylus bears about a dozen of teeth, of which the first two near the articulation are larger than the following. The fingers of the smaller cheliped bear each 15 or 16 teeth.

In the largest males the arms of the anterior legs project almost by their whole length beyond the carapace, in the youngest male only partly and in the females still less.

Dr. Calman has indicated in 1909 (Proc. Zool. Soc. London, p. 710) that the specimen, recorded under the name of Gecarcoidea Lalandii from "S. America" by ADAM WHITE in the "List of Crustacea in the British Museum 1847", has not been this species, so that no confirmation is afforded of MiLNE EDWARDS's statement that the type of the species has come from Brasil. Miss Rathbun (1.c.) considers Brazil as being also a doubtful locality and supposes that this species inhabits only indo-pacific islands. Gecarcoidea Lalandii is known from the following localities:

- Nicobar Islands, in dark, dense, damp forests (WoOD-MASON, Alcock); Andaman Islands (Alcock); Christmas Island (Pocock Andrews); Bay of Gorontalo, Celebes (DE MAN); Philippine Islands, Ile des Deux Soeurs (A. Milne Edwards); Loyalty Islands (A. Milne Edwards); New Britannia (ORTMANN). The westernmost locality is Clipperton Island at $109^{\circ}$ Long W., $10^{\circ}$ Lat. N., where five specimens were collected in 1896-1897 by Prof. Schauinsland (H. LenZ, Zoolog. Jahrb. XIV, Abth. f. Syst. 1901, p. 473).

This species lives in moist land or mud and migrates to the sea during the rainy season to hatch the eggs. Vast quantities of the megalopa-larva have been found in the sea shortly after migration; also, at a later date, the young crab. (RATHBUn, 1. c.).

\section{Cryptodromia canaliculata Stimpson.}

Cryptodromia canaliculata W. Stimpson, Proc. Acad. Nat. Sciences of Philadelphia, Dec. 1858, p. 240.

Cryptodromia canaliculata J. E. W. Ihle, Die Decapoda Brachyura der Siboga-Expedition. I. Dromiacea. Leiden 1913, p. 41 (Monographie XXXIXb) (ubi literatura).

Two adult males of equal size.

The carapace, measured at the first or anterior antero-lateral teeth, is $11 \mathrm{~mm}$. broad, while it is $10 \mathrm{~mm}$. long. Both belong to the typical form. In one specimen the 2nd antero-lateral tooth, though much smaller than the anterior, is well-developed, in the other the 2nd is rudimentary. In both specimens the triangular, subacute, middle frontal tooth reaches distinctly farther forward than the lateral, the tooth at the external orbital angle is rather obtuse. Not only the subhepatic, but also the tooth on the suprasutural ridge, which is smaller than the former, are well-developed and a small tubercle exists on the antero-external angle of the buccal frame; from the subhepatic tooth a slightly curved carina extends to the 2nd antero-lateral, that forms the outer part of the lower border of the channel, in which the antennal flagellum is lying. Dr. Alcock in his description of this species (Catalogue of the Indian Decapod Crustacea in the Collection of the Indian Museum. Part I. Brachyura. Calcutta 1901 , p. 50) makes no mention of the tooth on the suprasutural ridge, for the rest his description and the figure 8 on Pl. II are excellent. The tomentum of the upper surface of the carapace extends laterally to the first or anterior antero-lateral tooth and continues obliquely forward, at some distance from the orbital margin to a little behind the front; owing to this interruption of the tomentum the upper surface appears anteriorly like a channel. It was described by STIMPSON as follows „carapax juxta.margines frontales et antero-laterales canaliculatus, canaliculo fere nudo", so that from this pseudo-channel the specific name has been derived.

In his Key for the determination of the species of this genus Dr. IHLE distinguishes the two species canaliculata Stimpson and coronata Stimpson by the nodules of the carpus being obtuse in the former, acute in the latter. This distinction is rather vague; the different shape of the male abdomen is a more practical character, the terminal segment being in Crypt. canaliculata triangular, 
with the lateral margins concave and the posterior margin one and a half times as broad as the segment is long; in Crypt. coronata Stimpson, however, the terminal segment is semicircular, just half as long as broad at its base (J. G. DE MAN, in: Archiv für Naturg. 1888, Taf. XVIII, fig. $2 b$ ). In my figure, ibidem, of the whole animal the carapace of Crypt. coronata presents its greatest breadth at the level of the second, in the two males of Crypt. canaliculata, however, at that of the first antero-lateral teeth.

The upper surface of the carapace has a yellowish white colour; between the upper border of the orbits and the anterior boundary-line of the tomentum it is dark red, and a few red spots are visible on the cardiac and at either side of the gastric region; the 1 st and 2 nd pairs of ambulatory legs and the chelipeds show the same red colour, but the tips of the fingers are white; the two last legs are yellowish white and there are a few red spots on the abdomen.

Petrolisthes dentatus (H. M.-Edw.) var.

Petrolisthes dentatus (H. M.-Edw.) var., J. G. DE MAN, in: Zoolog. Jahrb. (Spengel) IX. Abth. f. Syst. 1896, p. 374, Taf. 32, fig. $47 a$.

Ten specimens of different size, belonging to the same variety as the 42 from Atjeh, described (1.c.).

The carapace of the largest specimen is $10,5 \mathrm{~mm}$. long and $10 \mathrm{~mm}$. broad; in this specimen the right cheliped is much larger than the left, also in another the left appears a little smaller than the right. Only in three individuals the epibranchial spine is well-developed, in the others the epibranchial angle appears at the utmost acute, but often it is even obtuse. Also in some of the specimens from Atjeh the spine was broken off or worn away, just as often takes place in the spines on the posterior border of the carpus of the chelipeds. Spinules on the anterior border of the meropodites of the ambulatory legs were not observed.

\section{Petrolisthes Boscii (Aud.).}

Porcellana Boscii Aud., J. G. DE MAN, in: The Journal of the Linnean Society, Zoology, Vol. XXII, London 1888, p. 217.

One male, one ova-bearing female, both adult and of equal size, and one much younger specimen.

This beautiful species may easily be distinguished from the preceding, besides by the sculpture of the upper surface of the carapace and the chelipeds, by the fingers that are tomentose at the inner side and by the existence of a spinule on the upper distal border of the merus of the chelipeds that articulates with the carpus, near the posterior end. Both in this species and in Petrol. dentatus (H. M.-Edw.) the carapace bears an epibranchial spine.

The carapace of the ova-bearing female is $8 \mathrm{~mm}$. long and just as broad.

\section{Clibanarius virescens Krauss.}

Clibanarius virescens (Krauss), J. G. DE MAN, in: The Journal of the Linnean Society of London, Vol. XXII, London 1888, p. 247.

One specimen.

This specimen has the same size as the larger specimen from Owen Island, which I have described in 1888, the carapace being $9 \mathrm{~mm}$. long, and it also fully agrees with it as regards the colouration. The chelipeds are of an olive-green colour, there are some white spots of different form and size on the upper border and outer side of the meri of the chelipeds, the spines on carpus and palm are yellow-ochre, like the fingers, the tips of which are black; the two following pairs of legs are also olive-green, which colour appears much darker on the distal end of the propodi and this distal end is marked, both on the outer and the inner side of the joints, with a yellow-ochre spot; the compressed dactyli present also this yellow-ochre colour, but the terminal claws are black and the dactyli are devoid of the olive-green band on their middle, that exists in the typical species. The 
upper surface of the carapace has a pale whitish green colour, with paler spots, abdomen greyish. Eyepeduncles $4,5 \mathrm{~mm}$. long, a little longer than the breadth $(3,5 \mathrm{~mm}$.) of the frontal border of the carapace; they are olive-green with a whitish ring immediately behind the somewhat dilated black corneae.

Peduncles of inner and outer antennae olive-green, flagella of the inner antennae orange, those of the outer dark blue.

Probably the Straits of Malacca are inhabited by a local variety.

\section{Coenobita clypeatus Latr.}

Coenobita clypeatus Latr., A. ALcock, Catalogue of the Indian Decapod Crustacea in the collection of the Indian Museum. Part II. Anomura. Fasciculus I. Pagurides. Calcutta 1905, p. 142, Plate XV, fig. 1, $1 a$.

One full-grown male and one full-grown, ova-bearing female.

In both specimens the carapace is $45 \mathrm{~mm}$. long. The soft parts of the abdomen are in both of a verdigris colour, the eggs are apricot-coloured.

\section{Coenobita cavipes Stimpson.}

Coenobita cavipes Stimpson, A. ALcock, 1. c. 1905, p. 146, Pl. XIV, fig. 1.

Coenobita violascens C. Heller, Crustaceen der Novara-Reise, 1865, p. 82, P1. VII, fig. 1.

Confer: J. G. DE MAN, in: Abhandl. Senckenb. Naturf. Gesellschaft, Bd. XXV, Frankfurt am Main 1902, p. 743 , Taf. XXIV, fig. 46 .

Two males of unequal size and one young female.

The carapace of the larger male, measured in the middle line, is $35 \mathrm{~mm}$. long, that of the other male $24 \mathrm{~mm}$., that of the female $23 \mathrm{~mm}$. These specimens belong to Coen. violascens Heller and also to the species that Alcock (1.c.) has described as Coen. cavipes Stimpson. In all the lower border of the outer surface of the propodus of the left third leg appears regularly concave, with no emargination at the proximal end, which was observed by me in specimens from Batjan and Ternate.

The upper surface of the gastric region and the legs have the characteristic violet colour of Coen. violascens.

$$
\text { Alpheus splendidus Cout. (P1. III, Fig. 8-8g). }
$$

Alpheus splendidus H. Coutière, in: Bulletin du Muséum d'hist. nat., Paris 1897, № 6, p. 235. Alpheus splendidus J. G. de Man, The Decapoda of the Siboga Expedition. Family Alpheidae. Leiden 1911, p. 343 and in: Archiv f. Naturgeschichte, 90. Jahrg. Berlin 1924, Abt. A. 2. Heft, p. 41, fig. 14.

This beautiful species, described in 1897 by Professor Coutière after a single female from Djibouti, found at low tide under stones, and of which I was enabled a few years ago to examine the type (1.c.), is represented in the collection from Pulau Berhala by a well-preserved specimen, long about $21 \mathrm{~mm}$.

The spiniform rostrum (Fig. 8 and $8 a$ ), 1,1 mm. long and 0,34 $\mathrm{mm}$. broad at its base, projects horizontally nearly to the distal extremity of basal antennular article, but the tip is slightly curved downward; the rostrum, which is thrice as long as broad at its base, is continued above the gastric region into a subacute compressed carina, to just behind the middle of the carapace; the upper border of this carina which is higher than the rostrum and the orbital hoods, appears in a lateral view convex. Anteriorly the carina is separated by deep grooves from the rounded, convex, orbital hoods; from the upper surface of each hood - not from its anterior margin - arises a sharp slender spine, which, slightly curved inward, extends horizontally forward, almost reaching to the middle of the rostrum. The distinctly faceted corneae project by half their length beyond the anterior margin of the orbital hoods. Telson (Fig. $8 b$ ) $2,7 \mathrm{~mm}$. long, presenting its greatest width of $1,5 \mathrm{~mm}$. at one-sixth its length from its anterior border, posterior margin $0,86 \mathrm{~mm}$. broad; proportion between the length and the greatest width 1,8, proportion between the greatest width and that of the posterior margin 1,75. Spinules of the upper surface rather small, $0,22 \mathrm{~mm}$. long, those of the anterior pair about twice as far distant from the midline as from the lateral margins, those of the posterior little 
farther from the midline than from the latter, the anterior pair situated $1 \mathrm{~mm}$., the posterior $1,6 \mathrm{~mm}$. from the anterior border of the telson. The upper surface is faintly grooved in the midline between the spines of the anterior pair, the groove, however, soon fades away both anteriorly and posteriorly. Posterior margin curved, little prominent; of the two spinules at the external angle the inner is $0,22 \mathrm{~mm}$. long, just as long as the spinules of the upper surface, the outer half as long, the inner extending by half its length beyond the posterior margin. Basal joint of uropods consisting of two sharp spines, of which the outer is twice as long as the inner, measuring nearly one-third the length of the outer uropod, the shape of which is visible in the figure; movable spine near the acute posterior extremity of the outer margin uncoloured; inner uropod oval, twice as long as broad, rounded.

Second joint of antennular peduncle one-third longer than thick, a little shorter than 1st, terminal joint little shorter than 2nd; stylocerite slender, acuminate, reaching almost to the middle of 2 nd antennular article. Antennal peduncle a little longer than that of the inner antennae, scale as long as the latter, terminal spine of the scale reaching as far forward as the carpocerite; spine on the basicerite reaching almost to the distal extremity of 1 st antennular article.

The merus of the larger cheliped (Fig. $8 c$ ), that is placed at the right side, is little more than twice as long as the greatest width of its outer surface, just behind the distal end, and slightly narrows backward; the upper margin is unarmed at the distal extremity, the infero-external margin is also unarmed, but the infero-internal is armed near the distal end with a sharp tooth or spine which is curved forward (Fig. 8d). Carpus short, about as deep or broad as its upper border is long. Chela $7 \mathrm{~mm}$. long, almost as long as the carapace, rostrum included $(7,75 \mathrm{~mm}$.); the palm $5 \mathrm{~mm}$. long, little more than twice as long as the fingers, $3 \mathrm{~mm}$. broad, the chela being a little more than twice as long as broad. The rounded upper border of the palm bears just behind the distal end a transverse groove that extends a little farther on the inner than on the outer surface and the posterior border of this groove bears a few fine setae; just below it one observes, on the outer surface of the palm, a longitudinal groove that does not extend to the distal border and that ends backward into the fine furrow of the elliptical area. The lower border of the chela is also notched, opposite to the transverse groove of the upper, the distal end of the palm appearing here truncate and from this groove a fine impressed longitudinal line proceeds at the inner side of the lower border of the palm to near the carpal articulation. The outer surface of the immobile finger is broadly grooved on its upper half to near the obtuse tip and some setae are implanted on the cutting-edge; the dactylus, the upper border of which is strongly curved, reaches with the obtuse tip a little beyond the other finger. The inner surface of the fixed finger appears also slightly concave in its upper part and the strongly curved upper border of this finger bears some long setae. Both the outer and the inner surface of the palm are smooth. Owing to these notches and grooves the chela looks like that of some species of the Edwardsii-Group, e.g. like that of $A$. Coutierei de Man from the Indian Archipelago.

Merus and carpus of the smaller cheliped resemble that of the larger but the merus is quite unarmed. Chela $10 \mathrm{~mm}$. long, one-third longer than that of the right cheliped, a little longer than the carapace, rostrum included, and about 5-times as long as broad; palm 4,5 mm. long, twice as long as broad, a little shorter than the fingers, smooth, with a trace of a shallow longitudinal groove on the upper border between the articulation of the dactylus and the elliptical area, and armed at either side of this articulation with an acute spine, the spine at the inner side larger than the other; cutting-edges of the fingers sharp, unarmed.

The legs of the $2^{\text {nd }}$ pair (Fig. $8 e$ ) resemble those of $A$. facetus de Man; the carpal segments are $1,4 \mathrm{~mm}$., $0,6 \mathrm{~mm}$., $0,4 \mathrm{~mm}$., $0,4 \mathrm{~mm}$. and $0,8 \mathrm{~mm}$. long, the chela $1,55 \mathrm{~mm}$. (palm $0,7 \mathrm{~mm}$., fingers $0,85 \mathrm{~mm}$.); chela twice as long as the 5 th segment of the carpus.

The following legs also much resemble those of $A$. facetus. A movable spine on the ischium of the $3^{\text {rd }}$ and 4 th legs was, however, not observed. Merus of 3rd legs (Fig. 8f ) 5,5-times as long as broad in the middle, propodus one and a half times as long as the carpus, 7,5-times as long as broad, with 8 spinules on the posterior margin, two of which are implanted at the distal end, upper border setose, its distal extremity with 3 or 4 setae, of which the longest is $0,56 \mathrm{~mm}$. long, reaching to the middle of the dactylus; dactylus (Fig. $8 g$ ) measuring one-third the length of the propodus, 4,6-times 
as long as broad at its base, acuminate, with a microscopical spinule on the upper border, at onethird its length from the tip.

The beautiful colour of this species is described by CoutiéRE in the following words: „Une étroite bande jaune vif du rostre au telson, bordée de deux bandes brunes; le reste du corps rougeâtre, sauf deux étroites lignes blanches contiguës aux bandes brunes; pinces orange clair." In the specimen from Pulau Berhala a cream-coloured band extends, at first narrow, then gradually widening, from the rostrum to the posterior margin of the 6 th segment of the abdomen; this band appears broadest on the 3 rd and $4^{\text {th }}$ segment, its breadth being here one-third that of the segments; on the 5th and 6 th it again decreases in width. At either side this band is flanked by another of a pale red colour, nearly as broad as the median one while the lateral sides of the carapace and the abdominal pleura are again cream-coloured; the posterior part of the telson, the outer border of the inner uropod and the transverse dentate ridge on the outer are pale red, like also the outer border of the basicerite and scaphocerite, the chelae pale red. Probably; however, the coloration of our specimen has partly faded away.

The nearest related species is certainly $A$. facetus de Man from Pajunga Island, Kwandang-bay and from Pulu Jedan, east coast of Aru-islands. (J. G. DE MAN, 1.c. 1911, p. 340, 1915, Pl. XIV, fig. 67-67f). In $A$ facetus, however, the orbital spines arise from the anterior border of the orbital hoods, not from their upper surface, and this border presents at either side of the rostrum a prominence, that does not exist in A. splendidus. The posterior pair of spinules on the upper surface of the telson is farther distant from the anterior pair than from the posterior margin, in A. splendidus, however, farther distant from the latter than from the anterior pair of spinules. The movable spine near the postero-external angle of the outer uropod is black. The larger cheliped is almost 3-times as long as high, of a more slender shape; neither the upper nor the lower border are notched, the upper border of the palm presents a longitudinal groove, that runs from near the articulation of the dactylus, gradually narrowing, to that of the carpus. The characteristic coloration of Coutıère's species, finally, is wanting.

Alpheus chiragricus H. M.-Edw.

Alpheus chiragricus H. M.-Edw., J. G. DE MAN, 1. c. 1911, p. 415.

Several specimens, some of which may, however, belong to A. crassimanus Heller or to $A$. Audouini Cout.; it could not be determined with certainty, because in these specimens the anterior legs or one of them are wanting.

Gonodactylus chiragra (Fabr.) var. intermedia n. (P1 III, Fig. 9-9b).

One specimen.

This specimen is $45 \mathrm{~mm}$. long from tip of rostrum to the ends of the submedian marginal teeth of the telson. It is of a pale yellowish-green colour, the distal extremity of the propodus of the raptorial claw is indigo-blue, like also the strongly inflated basal portion of the dactylus, and this basal portion is at the outer side reddish coloured; the curved upper border of the merus is marked with two brownish spots and a dark brownish spot exists on the antero-external angle of the 1st - 5 th segments of the abdomen.

The type, long $56 \mathrm{~mm}$., from Elphinstone Island, Mergui Archipelago, on which, the variety acutirostris was established by me in 1898 (in: Zoolog. Jahrbücher, X, Abth. f. Syst., p. 695, fig. $77 b$ and $77 c$ ) is preserved in my private collection, furthermore a typical specimen of Gonod. chiragra (Fabr.) from Pulau Edam in the Bay of Batavia (J. G. DE MAN, in: Archiv f. Naturg. 53. Jahrg. 1888, p. 573) and a cotype of the variety affinis de Man from Ternate (J. G. DE MAN, in: Abhandl. Senckenb. Naturf. Gesells., Bd. XXV, Frankfurt a/M. 1902, p. 912). The specimen from Pulau Edam has the same size as the type of the variety acutirostris, viz., 55 or $56 \mathrm{~mm}$. and most agrees with the variety incipiens $b$ of LANCHESTER (W. F. LANCHESTER, in: Fauna and Geography of the Maldive and Laccadive Archipelagoes, Vol. I, Part 4, 1903, p. 451, Pl. XXIII, fig. 11), though not fully. The 
small tubercle on either side of the telson close by the anterior margin just behind the 2 nd keel of the $6^{\text {th }}$ segment (considering the lateral keel as the 1st), which in LANCHESTER's figure 11 is wanting, is well-developed; the median keel on the upper surface is narrower, the lateral keels are not curved, but parallel with the median one and the keel on the intermediate marginal teeth reaches a little farther forward. The median spine of the rostrum extends to the corneae of the eyestalks, the anterolateral angles are obtusely rounded.

As regards the type of the variety acutirostris I am obliged to correct a mistake in the original description (in: Zoolog. Jahrb. X. Abth. f. Syst 1898, p. 695, Taf. 38, fig. $77 b$ and $77 c$ ). One reads there even in letters that are spaced out "Die zwei accessorischen Höcker auf dem Telson fehlen": this is not the case, on either side a small tubercle is observed close by the anterior margin, immediately posterior to the 2nd keel of the 6 th somite. This tubercle was evidently overlooked by $\mathrm{me}$ in 1898 . The variety acutirostris is, however, quite well characterized $1^{0}$ by the angles of the rostrum that are sharp and acute, $2^{\circ}$ by the keels of the submedian or posterior teeth of the telson-edge that distinctly converge forward, $3^{0}$ by the shape of the keels on the 6 th somite and the telson.

The remarkable specimen that was collected by Mr. J. C. VAN DER MEer MOHR at Pulau Berhala, agrees with the var. acutirostris as regards the shape of the rostrum, but differs by the characters of the telson, so that this specimen forms a transition between the former and the varieties of the typical Gonod. chiragra, described by Dr. BorRADAILE in his valuable paper of 1907 (in: The Transact. Linnean Soc. of London, 2nd Ser., Zoology, Vol. XII, Part 2, p. 211). The rostrum, which in the type of the var. acutirostris reaches to the middle of the terminal joint of the eyestalks, to the proximal end of the corneae, extends in the specimen from Pulau Berhala only to the base of that terminal joint; the lateral angles are just as sharpand acute as in the type of the variety acutirostris, directed obliquely forward. The 6th segment and the telson, however, fully agree with those of the specimen from Pulau Edam, except that there is a minute spinule (Fig. 9c), curved upward, at the posterior end of the median keel of the telson and that the lateral keels of the upper surface are slightly curved; the two sharp spines also, in which the ventral process of the uropods terminates, are in proportion to the rest of the process a little longer. Other differences are not observed.

The variety intermedia is thus found in the immediate neighbourhood of the variety acutirostris. 


\section{EXPLANATION OF THE PLATES.}

\section{PLATE I.}

Fig. 1. Actumnus changensis Rathbun. Antero-lateral part of the upper surface of the male, $\times 37^{1 / 2}$.

Fig. 2-2d. Litocheira subintegra (Lanch.). Male from Elphinstone Island. 2 carapace and left leg of $5^{\text {th }}$ pair $\times 4 \frac{1}{2} ; 2 a$ antero-lateral part of the upper surface, $\times 11^{1} / 4 ; 2 b$ front and orbits looked at from before, $\times 71 / 2 ; 2 c$ front viewed from above, $\times 15 ; 2 d$ abdomen, $\times 11 \frac{1}{4}$

Fig. 3-3c. Litocheira splendida de Man. 3 The younger male, $\times 4 \frac{1}{2} ; 3 a$ antero-lateral part of the carapace of the larger male, $\times 18^{3} / 4 ; 3 b$ anterior part of carapace, lower surface, of this male, $\times 6^{3} / 4 ; 3 c$ carapace of this male, viewed from before, $\times 6^{3} / 4$.

\section{PLATE II.}

Fig. $3 d-3 f$. Litocheira splendida de Man. $3 d$ abdomen of the younger male, $\times 13^{1 / 2} ; 3 e$ carpus and chela, outer side, $\times 6^{3} / 4 ; 3 f$ right leg of $5^{\text {th }}$ pair of the younger male, $\times 9$.

Fig. 4-4g. Litocheira integra (Miers). Female from the reef at Hulule, Male Atoll. 4 carapace and right leg ot the $5^{\text {th }}$ pair, $\times 7^{1 / 2} ; 4 a$ front, orbits and antennal region, looked at from above, $\times 18^{3 / 4} ; 4 b$ median incision of the front, $\times 37 \frac{1}{2} ; 4 c$ antero-lateral part of upper surface, $\times 18^{3} / 4 ; 4 d$ right half of carapace, anterior part, lower side, $\times 37 \frac{1}{2} ; 4 e$ smaller chela, $\times 11^{1} / 4 ; 4 f$ distal half of the fingers, $\times 18^{3} / 4 ; 4 g$ right leg of $5^{\text {th }}$ pair, $\times 18^{3} / 4$.

Fig. 5-5b. Pinnotheres palaensis Bürger. 5 terminal parts of external maxilliped of a male long $4,5 \mathrm{~mm}$., inner side, $\times 51 ; 5 a$ the same parts of an egg-bearing female, the carapace of which is $8,7 \mathrm{~mm}$. long, $\times 51 ; 5 b$ left cheliped, outer side, of a young female, the carapace of which is $5,5 \mathrm{~mm}$. long, $\times 15$.

\section{PLATE III.}

Fig. 6-6f. Grapsus gracilipes H. M.-Edw. Full-grown male from Pulau Berhala. 6 Front, looked at from above, $\times 1 \frac{1}{8} ; 6 a$ front looked at from before, $\times 1^{1 / 8} ; 6 b$ epistome, $\times 1^{1 / 8} ; 6 c$ last and penultimate segment of abdomen, $\times 1^{1 / 8} /$ $6 d$ upper view of carpus of the right cheliped, $\times 1 \frac{1}{8} ; 6 e$ right leg of the penultimate pair, $\times 11 / 8 ; 6 f$ right leg of the last pair, $\times 1 \frac{1}{8}$.

Fig. 7. Grapsus grapsus (Linné). Upper view of the carpus of the right cheliped of the male from the Bahama Islands, $\times 1 \frac{1}{8}$

Fig. 8-8g. Alphetus splendidus Cout. Specimen from Pulau Berhala. 8 anterior part of carapace with the peduncles of the inner and outer antennae, $\times 15 ; 8 a$ lateral view of rostrum, $\times 15 ; 8 b$ telson and left uropods, $\times 15 ; 8 c$ larger cheliped; outer side, $\times 10 ; 8 d$ distal extremity of the merus of this cheliped, $\times 15 ; 8 e \operatorname{leg}$ of $2^{\text {nd }}$ pair, $\times 15 ; 8 f$ leg of $3^{\text {rd }}$ pair, outer side, $\times 15 ; 8 g$ dactylus of this leg, $\times 50$.

Fig. 9-9c. Gonodactylus chiragra (Fabr.) var. intermedia de Man. 9 rostrum, $\times 11 \frac{1}{4} ; 9 a$ sixth segment of abdomen and telson, $\times 51 / 2 ; 9 b$ left submedian tooth of telson-edge, $\times 25 ; 9 c$ posterior extremity of the median tubercle, with the microscopical spinule, $\times 22^{1 / 2}$ 

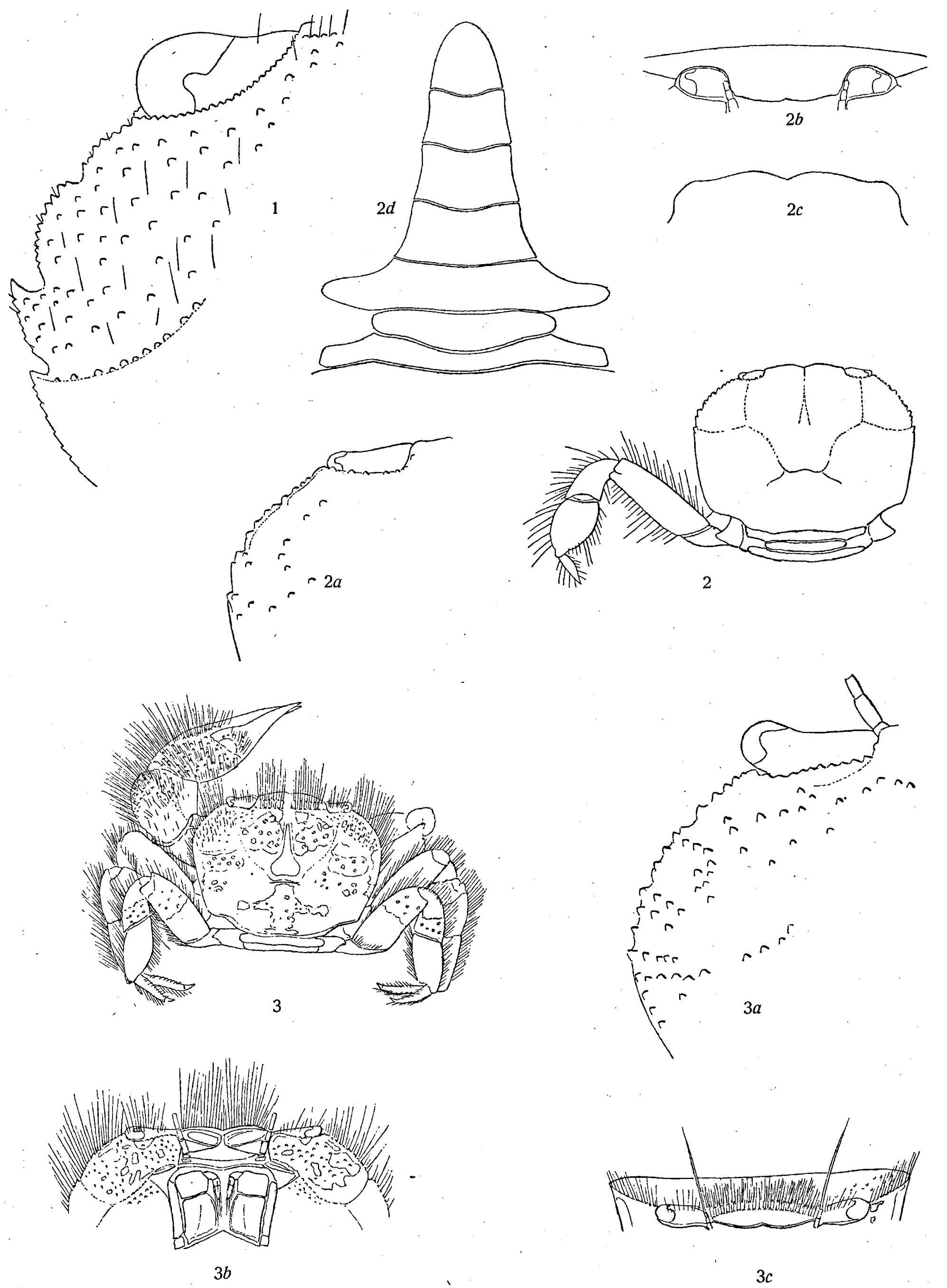

J. G. DE MAN, del,

$$
3 b
$$


BIJDRAGEN TOT DE DIERKUNDE, XXVI. - J. G. DE MAN.

II.

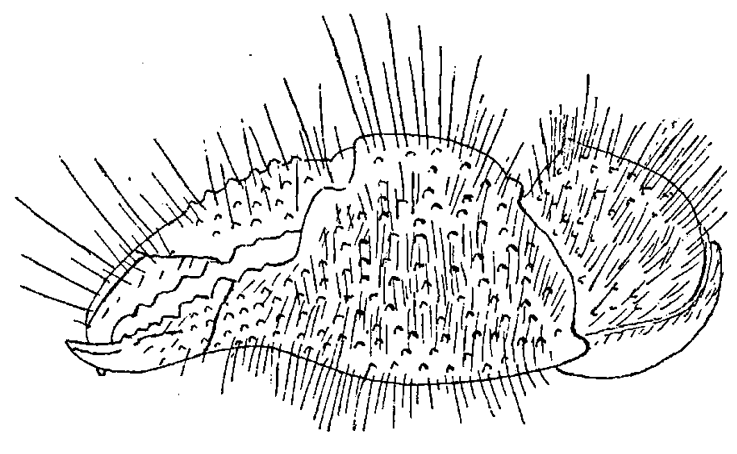

$3 e$
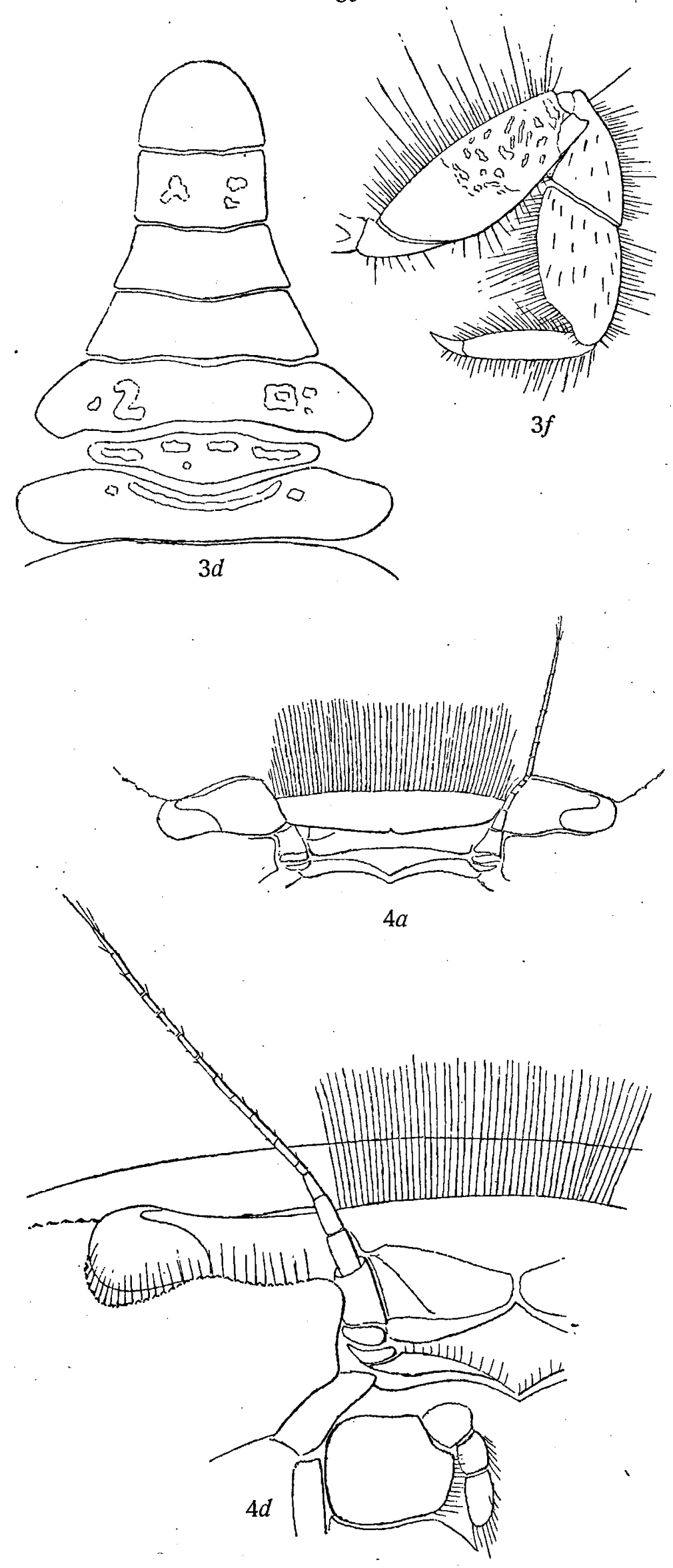

J. G. DE MAN, del.
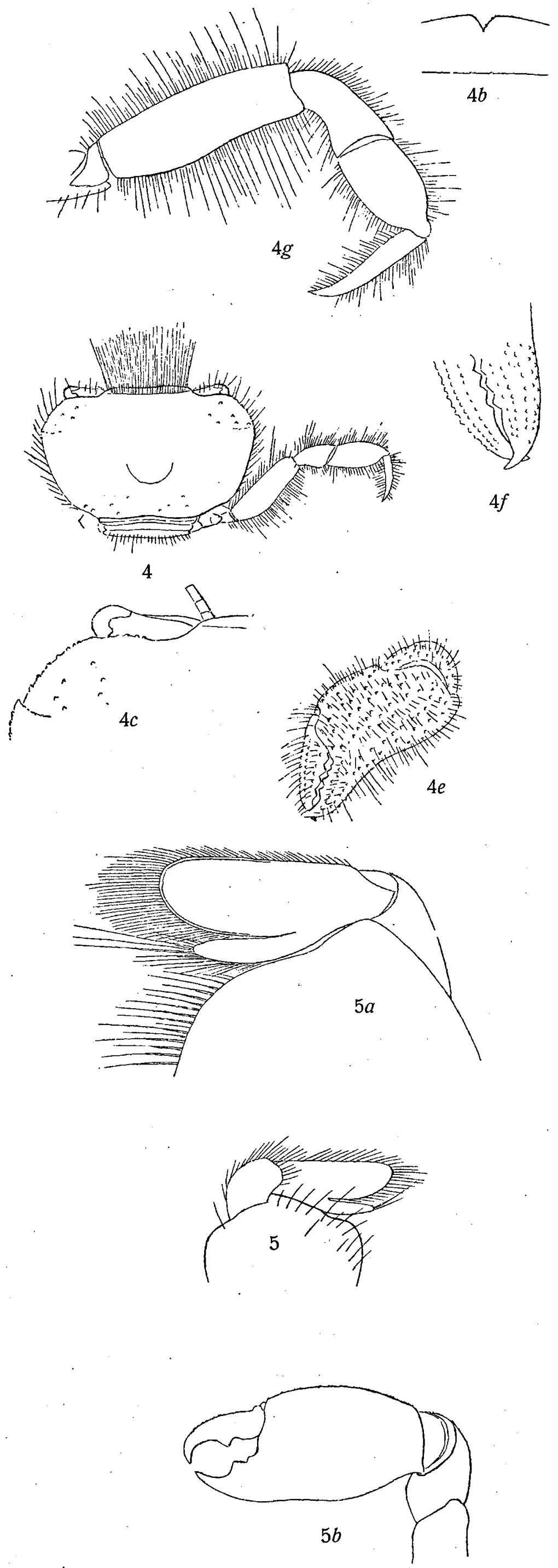
BIJDRAGEN tOT DE DIERKUNDE, XXVI. - J. G. DE Man.

III.
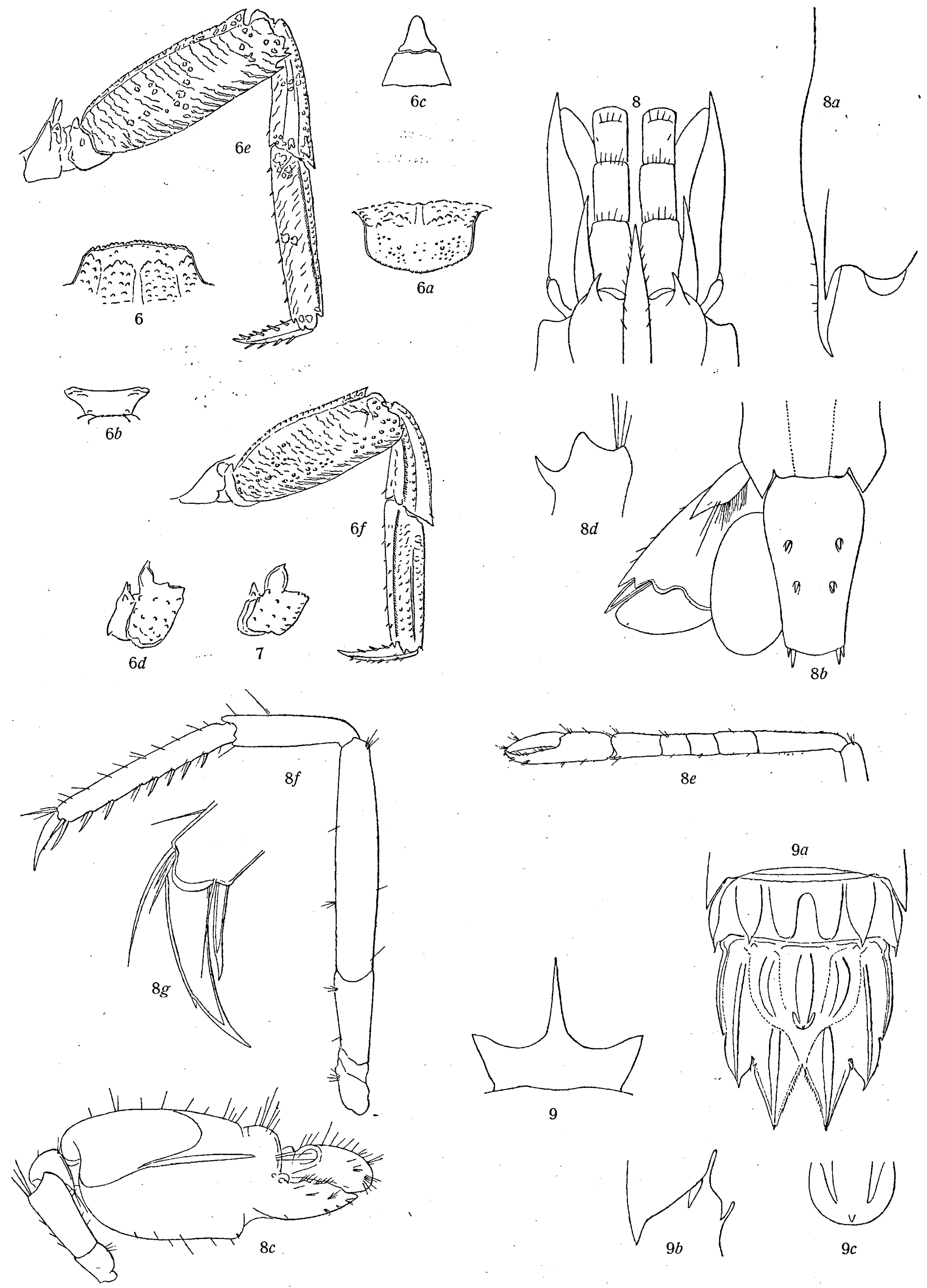

J. G. DE MAN, del. 